\title{
Polyphenols in the Mediterranean Diet: From Dietary Sources to microRNA Modulation
}

\author{
Roberto Cannataro $^{1,2} \mathbb{D}^{\text {, }}$, Alessia Fazio ${ }^{1}$, Chiara La Torre ${ }^{1,2}$, Maria Cristina Caroleo ${ }^{1,2, *}$ and Erika Cione ${ }^{1,2} \mathbb{D}$ \\ 1 Department of Pharmacy, Health and Nutritional Sciences, Department of Excellence 2018-2022, \\ University of Calabria, Edificio Polifunzionale, 87036 Rende (CS), Italy; r.cannataro@gmail.com (R.C.); \\ alessia.fazio@unical.it (A.F.); latorre.chiara@libero.it (C.L.T.); erika.cione@unical.it (E.C.) \\ 2 GalaScreen Laboratories, Department of Pharmacy, Health and Nutrition Sciences, University of Calabria, \\ 87036 Rende (CS), Italy \\ * Correspondence: mariacristina.caroleo@unical.it
}

Citation: Cannataro, R.; Fazio, A.; La Torre, C.; Caroleo, M.C.; Cione, E. Polyphenols in the Mediterranean Diet: From Dietary Sources to microRNA Modulation. Antioxidants 2021, 10, 328. https://doi.org/10.3390/antiox10020328

Academic Editor: Maria

Cristina Albertini

Received: 1 February 2021

Accepted: 16 February 2021

Published: 23 February 2021

Publisher's Note: MDPI stays neutral with regard to jurisdictional claims in published maps and institutional affiliations.

Copyright: (c) 2021 by the authors. Licensee MDPI, Basel, Switzerland. This article is an open access article distributed under the terms and conditions of the Creative Commons Attribution (CC BY) license (https:// creativecommons.org/licenses/by/ $4.0 /)$.

\begin{abstract}
It is now well established that polyphenols are a class of natural substance that offers numerous health benefits; they are present in all plants in very different quantities and types. On the other hand, their bioavailability, and efficacy is are not always well proven. Therefore, this work aims to discuss some types of polyphenols belonging to Mediterranean foods. We chose six polyphenols-(1) Naringenin, (2) Apigenin, (3) Kaempferol, (4) Hesperidin, (5) Ellagic Acid and (6) Oleuropein-present in Mediterranean foods, describing dietary source and their chemistry, as well as their pharmacokinetic profile and their use as nutraceuticals/supplements, in addition to the relevant element of their capability in modulating microRNAs expression profile.
\end{abstract}

Keywords: polyphenols; nutraceutical; microRNA; epigenomic

\section{Introduction}

Angel Keys, a biologist and physiologist who based his conclusions on his studies focusing on the dietary habits of people living in Southern Italy, was the first to present the phrase "Mediterranean diet" to the popular imagination, investing it with a scientific and cultural meaning. Now, following the joint candidacy of Italy, Spain, Greece and Morocco, followed by Cyprus, Croatia and Portugal, it has the recognition of not only UNESCO, but also of the WHO and FAO. The Mediterranean diet varies by country and region, so it has a range of definitions. In general, however, it is high in vegetables, fruits, legumes (such as beans), nuts, cereals, fish and unsaturated fats (such as olive oil). It usually includes a low intake of meat and dairy foods. In particular, some plants are characteristic of the Mediterranean vegetation; some have been present for thousands of years, such as olive trees, walnuts, oregano, pomegranates, onions and others including various citrus species [1]. The Mediterranean diet represents one of the first examples of a positive correlation between diet and cardiovascular health; in fact, a diet that involves the frequent eating of fruit and vegetables, possibly in season, in addition to seeds and olive oil, has been shown to exhibit significant benefits in health terms, resulting not only in preventing cardiovascular disease, but also diabetes, obesity and even various forms of cancer [2-5], although the dietary polyphenol intake in Europe seems to be high in the north [6]. This effect can be explained, at least in part, by the regular and varied intake of food polyphenols that characterize the Mediterranean diet. Although there is no set recommended daily dose, polyphenols have an important role in modulating and preventing various diseases, such as cardiovascular [6], as well as inflammatory diseases such as arthritis [7]. Probably the most important actions by polyphenols are carried out in the regulation and management of reactive oxygen species (ROS) and immunomodulation. The pathways that are influenced by much of them are those of nuclear factor kappa-lightchain-enhancer of activated B cells (NF-kB), mitogen-activated protein Kinase (MAPK) and 
arachidonic acids and phosphatidylinositide 3-kinases/protein kinase B (PI3K/AkT) as an inhibitor. On the other hand, they upregulate superoxide dismutase (SOD), catalase and glutathione peroxidase (GPx) expression: GPR40 [8-11].

Polyphenols are very often linked to the colors of the plants that contain them. They are present in practically all plant species and in various parts of the plant itself, especially in the leaves, fruits and roots [12]. On the other hand, while showing promising in vitro activity, they often present the obstacle of bioavailability, which does not always make them so useful if tested directly on humans. Polyphenols have a typical molecular structure with one or more aromatic rings, and one or more double bonds are present in the molecule. This structure guarantees an antioxidant action for all classes, as there is delocalization of the free radical itself, with consequent antioxidant activity. [12]. Together with this, polyphenols have a genomic and epigenomic action, in fact there are numerous studies that underline their regulatory action, among others, on NF- KB, MAPK and nuclear factor erythroid related factor 2 (Nrf2) $[11,13,14]$. In addition to that, they show epigenetic activity in modulating microRNAs expression and from this point of view the microRNAs could represent a useful evaluation tool to study polyphenols action in human. In this review, we choose six polyphenols-(1) Naringenin, (2) Apigenin, (3) Kaempferol, (4) Hesperidin, (5) Ellagic Acid and (6) Oleuropein - present in Mediterranean foods, as this dietetic lifestyle is linked to better health status [2-5].

\section{Dietary Sources}

\subsection{Naringenin}

Naringenin is especially abundant in rosemary $(55.1 \mathrm{mg} / 100 \mathrm{~g})$ and present in grapefruit juice $(37.76 \mathrm{mg} / 100 \mathrm{~mL})$, red wine $(0.75 \mathrm{mg} / 100 \mathrm{~mL})$ and orange juice $(0.07 \mathrm{mg} / 100 \mathrm{~mL})$ (Figure 1). Naringenin is a flavonoid belonging to the subclass of flavanones, also often found in food in its glycosides form. [15].

\begin{tabular}{|c|c|c|}
\hline Dietary sources & $\begin{array}{c}\text { Phenol-Explorer } \\
\mathrm{mg} / \mathbf{1 0 0 g}-\mathbf{m g} / \mathbf{1 0 0} \mathbf{m L}\end{array}$ & $\begin{array}{c}\text { USDA } \\
\mathbf{m g} / \mathbf{1 0 0 g}-\mathbf{m g} / \mathbf{1 0 0} \mathbf{m L}\end{array}$ \\
\hline Rosmary & 55.1 & 24.76 \\
Grapefruit juice & 37.76 & 32.64 \\
Red wine & 0.75 & 1.77 \\
Orange juice & 0.07 & 1.63 \\
\hline
\end{tabular}

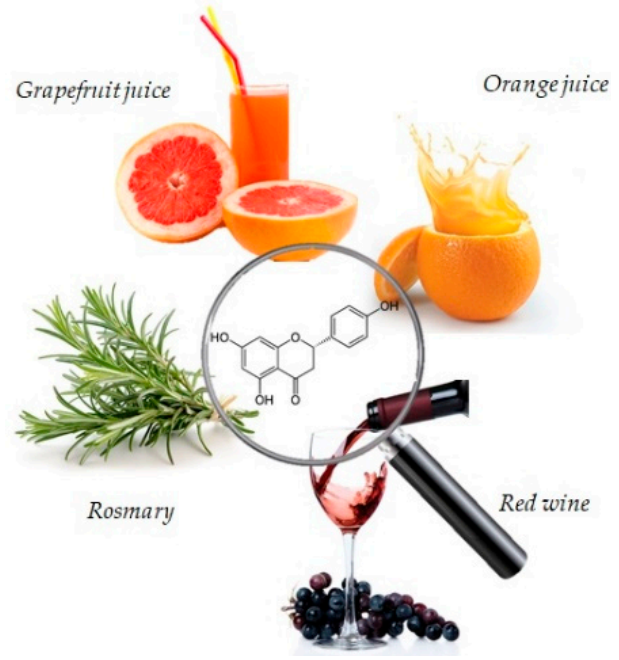

Figure 1. Main foods and beverages that contain naringenin, according to the database PhenolExplore (http:/ / phenol-explorer.eu/ accessed on 29 January 2021) and USDA Database for the flavonoid content of selected foods (https:/ / www.ars.usda.gov/ accessed on 13 February 2021).

\subsection{Apigenin}

The name apigenin derives from the genus Apium in the Apiaceae also known as Umbelliferae and is found as a unique ingredient in chamomile (Matricaria chamomilla), an annual herb native to western Asia and Europe. Drinks prepared from chamomile contain from $0.8 \%$ to $1.2 \%$ of apigenin. Apigenin is abundant in a variety of other dietary sources [16], including fruits and vegetables (Figure 2), such as celery seeds $(78.65 \mathrm{mg} / 100 \mathrm{~g})$, spinach $(62.0 \mathrm{mg} / 100 \mathrm{~g})$, parsley $(45.04 \mathrm{mg} / 100 \mathrm{~g})$, marjoram $(4.40 \mathrm{mg} / 100 \mathrm{~g})$, Italian oregano ( $3.5 \mathrm{mg} / 100 \mathrm{~g})$, sage $(2.40 \mathrm{mg} / 100 \mathrm{~g})$, chamomile ( 3 to $5 \mathrm{mg} / 100 \mathrm{~g})$ and pistachio $(0.03 \mathrm{mg} / 100 \mathrm{~g})$, but the richest sources are the respective dried sources. [17]. 


\begin{tabular}{|c|c|c|}
\hline Dietary sources & $\begin{array}{c}\text { Phenol-Explorer } \\
\mathrm{mg} / \mathbf{1 0 0 g}-\mathbf{m g} / \mathbf{1 0 0} \mathbf{~ m L}\end{array}$ & $\begin{array}{c}\text { USDA } \\
\mathbf{m g} / \mathbf{1 0 0}-\mathbf{m g} / \mathbf{1 0 0} \mathbf{~ m L}\end{array}$ \\
\hline Celery seeds & 78.65 & 78.65 \\
\hline Spinach & 62.0 & 0.00 \\
\hline Parsley & 45.04 & 45.04 \\
\hline Marjoram & 4.40 & 3.5 \\
\hline Oregano & 3.50 & 0.00 \\
\hline Sage & 2.40 & 1.20 \\
\hline Oil (extra virgin) & 1.17 & 0.09 \\
\hline Rosemary & 0.55 & 0.55 \\
\hline Chamomile & $3-5$ & Not present \\
\hline Pistachio & 0.03 & 0.00 \\
\hline
\end{tabular}
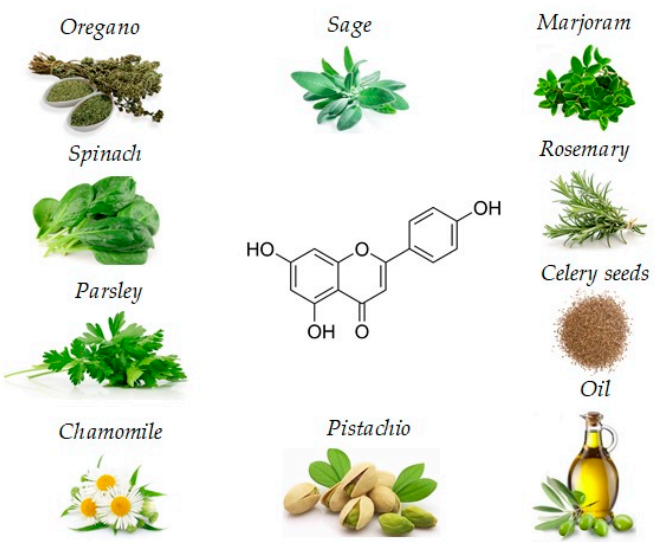

Figure 2. Main foods that contain apigenin, according to the database Phenol-Explore (http:/ / phenolexplorer.eu/ accessed on 29 January 2021) and USDA Database for the flavonoid content of selected foods (https:/ / www.ars.usda.gov/ accessed on 13 February 2021).

\subsection{Kaempferol}

The richest plant sources of kaempferol are green leafy vegetables, such as spinach (55 mg/100 g), cabbage (47 mg/100 g) and broccoli $(7.2 \mathrm{mg} / 100 \mathrm{~g})$, but also in onions ( $4.5 \mathrm{mg} / 100 \mathrm{~g}$ ) and blueberries ( $3.17 \mathrm{mg} / 100 \mathrm{~g})$. Regarding drinks, kaempferol is mainly present in black tea $(1.7 \mathrm{mg} / 100 \mathrm{~mL})$ and red wine $(0.23 \mathrm{mg} / 100 \mathrm{~mL})$. A good percentage is also present in spices such as capers $(104.29 \mathrm{mg} / 100 \mathrm{~g})$, cumin $(38.6 \mathrm{mg} / 100 \mathrm{~g})$ and cloves $(23.8 \mathrm{mg} / 100 \mathrm{~g})$ (Figure 3).

\begin{tabular}{|c|c|c|}
\hline Dietary sources & $\begin{array}{c}\text { Phenol-Explorer } \\
\mathrm{mg} / 100 \mathrm{~g}-\mathrm{mg} / 100 \mathrm{~mL}\end{array}$ & $\begin{array}{c}\text { USDA } \\
\mathrm{mg} / 100 \mathrm{~g}-\mathrm{mg} / 100 \mathrm{~mL}\end{array}$ \\
\hline \multicolumn{3}{|l|}{ Vegetable foods } \\
\hline Spinach & 55.0 & 6.38 \\
\hline Cabbuge & 47.0 & 0.18 \\
\hline Broccoli & 7.2 & 7.84 \\
\hline Onion & 4.5 & 4.1 \\
\hline Blueberry सुके & 3.50 & 1.66 \\
\hline \multicolumn{3}{|l|}{ Spices } \\
\hline Cappers & 104.29 & 259.19 \\
\hline Cumin & 38.6 & Not present \\
\hline Cloves & 23.8 & Not present \\
\hline \multicolumn{3}{|l|}{ Drinks } \\
\hline Black tea & 1.7 & 1.41 \\
\hline Red wine & 0.23 & 0.03 \\
\hline
\end{tabular}

Figure 3. Main foods and beverages that contain kaempferol, according to the database PhenolExplore (http://phenol-explorer.eu/ accessed on 29 January 2021) and USDA Database for the flavonoid content of selected foods (https:/ / www.ars.usda.gov/ accessed on 13 February 2021). 


\subsection{Hesperidin}

Hesperidin and its aglycone, hesperetin, are two flavonoids, which together with rutin and quercetin, are the main compounds of citrus fruits and, for this reason, this compound is called "citroflavonoid". It is present mainly in blood orange $(43.71 \mathrm{mg} / 100 \mathrm{~mL})$, mandarin juice $(36.11 \mathrm{mg} / 100 \mathrm{~mL})$, blond orange juice $(25.85 \mathrm{mg} / 100 \mathrm{~mL})$, lemon $(17.81 \mathrm{mg} / 100 \mathrm{~mL})$ and lime (13.41 mg/100 g) (Figure 4). The presence of this compound has also been detected in plants; a high value is reported in peppermint $(480.65 \mathrm{mg} / 100 \mathrm{~g})$.

\begin{tabular}{|c|c|c|}
\hline Dietary sources & $\begin{array}{c}\text { Phenol-Explorer } \\
\mathrm{mg} / \mathbf{1 0 0 g}-\mathbf{m g} / \mathbf{1 0 0} \mathbf{m L}\end{array}$ & $\begin{array}{c}\text { USDA } \\
\mathbf{m g} / \mathbf{1 0 0}-\mathbf{m g} / \mathbf{1 0 0} \mathbf{~ m L}\end{array}$ \\
\hline Peppermint & 480.65 & 10.16 \\
\hline Orange blood & 43.71 & 21.87 \\
\hline Mandarin & 36.11 & 7.94 \\
\hline Orange blond & 25.85 & 16.38 \\
\hline Lemon & 17.81 & 14.47 \\
\hline Lime & 13.41 & 8.97 \\
\hline
\end{tabular}

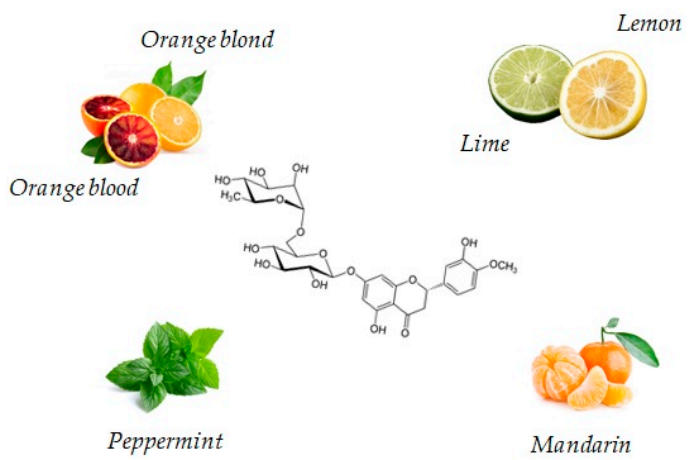

Figure 4. Main foods that contain hesperidin according to the database Phenol-Explore (http:// phenol-explorer.eu/ accessed on 29 January 2021) and USDA Database for the flavonoid content of selected foods (https:/ / www.ars.usda.gov/ accessed on 13 February 2021).

\subsection{Ellagic Acid}

Ellagic acid, a dilactone of the dimer gallic acid, is a polyphenol found in fruit and vegetables. Some foods contain a more complex version called ellagitannin, which will be converted into ellagic acid by organism. Ellagic acid is prevalent in berries (Figure 5). Foods high in ellagic acid are chestnut $(735.44 \mathrm{mg} / 100 \mathrm{~g})$, blackberries $(43.67 \mathrm{mg} / 100 \mathrm{~g})$, black raspberries $(38 \mathrm{mg} / 100 \mathrm{~g})$, walnuts $(28.50 \mathrm{mg} / 100 \mathrm{~g})$, cloudberries $(15.30 \mathrm{mg} / 100 \mathrm{~g})$, pomegranate juice $(2.06 \mathrm{mg} / 100 \mathrm{~mL})$, strawberries $(1.24 \mathrm{mg} / 100 \mathrm{~g})$, red raspberries $(1.14 \mathrm{mg} / 100 \mathrm{~g})$ and muscadine grape $(0.90 \mathrm{mg} / 100 \mathrm{~g})$ [18]. Ellagic acid is synthetized by plants as a defense mechanism against infections and parasites.
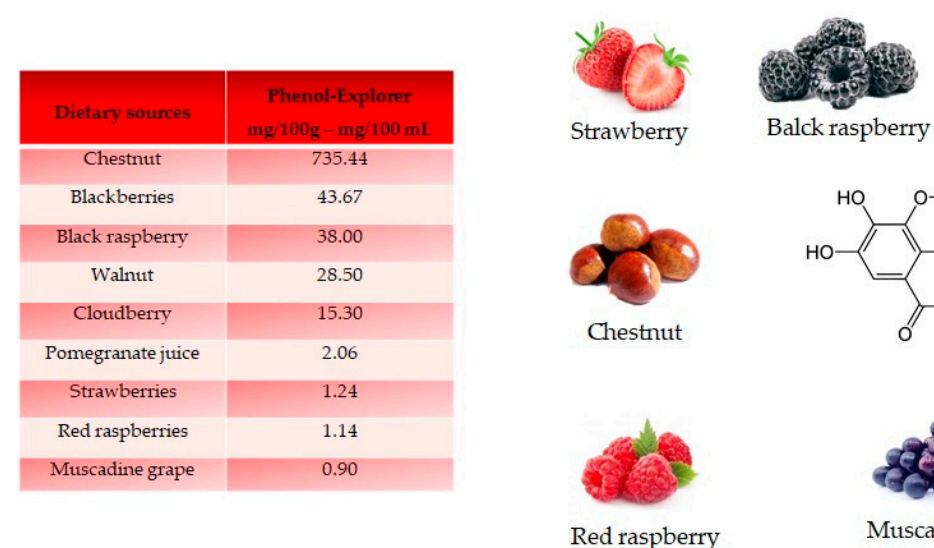

Balck raspberry
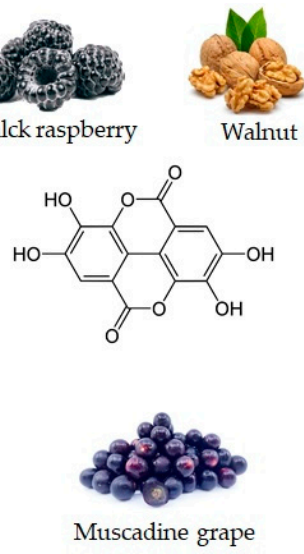
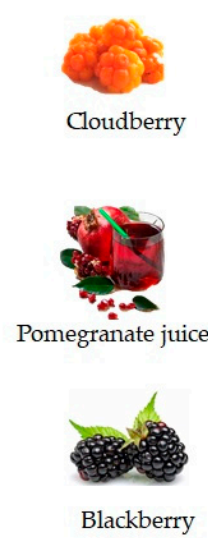

Figure 5. Structure and main foods that contain ellagic acid, according to the database PhenolExplore (http:/ / phenol-explorer.eu/ accessed on 29 January 2021). There is no value reported for the USDA Database for the flavonoid content of selected foods (https:/ / www.ars.usda.gov / accessed on 13 February 2021).

\subsection{Oleuropein}

Oleuropein is the molecule responsible for the bitter taste of olives and is the most common phenolic component in the leaves, seeds, pulp and skin of unripe olives. Although 
abundant, this compound undergoes hydrolysis during fruit ripening leading to the production of other important compounds such as hydroxytyrosol and ester derivatives [19]. It is important to underline that the oleuropein content may also depend on the variety of the olive (in fact black and green olives contain $72.02 \mathrm{mg} / 100 \mathrm{~mL}$ and $55.58 \mathrm{mg} / 100 \mathrm{~mL}$, respectively (Figure 6)), but also, and above all, on the processing techniques used to obtain the oil [20].

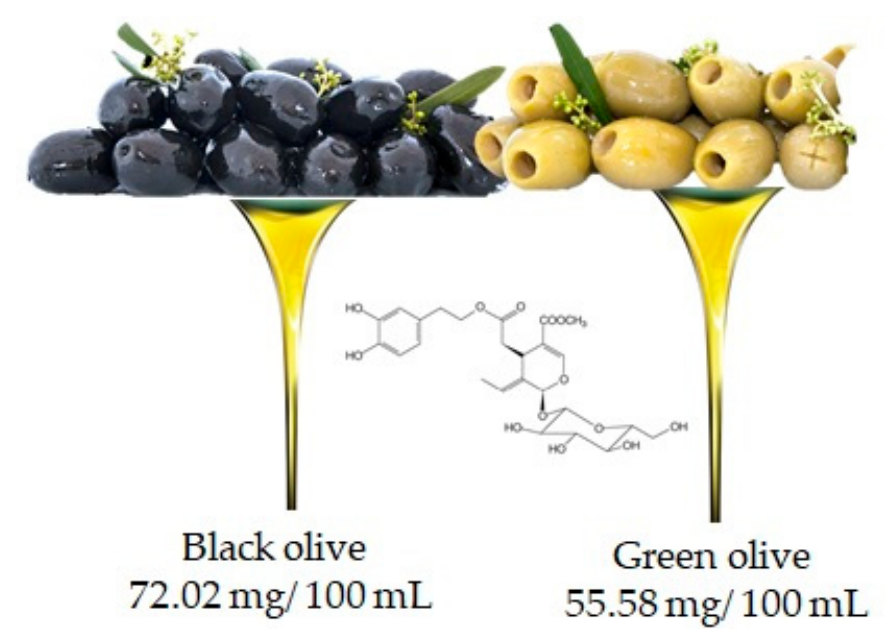

Figure 6. Olive is the main food that contains oleuropien, according to the database Phenol-Explore (http:/ / phenol-explorer.eu / accessed on 29 January 2021). There is no value reported for the USDA Database for the flavonoid content of selected foods (https://www.ars.usda.gov/ accessed on 13 February 2021).

\section{Chemistry}

Polyphenols are natural compounds synthesized exclusively by plants and characterized by two phenyl rings at least and one or more hydroxyl substituents. This description comprehends a large number of heterogeneous compounds with reference to their complexity. All phenolic compounds are synthesized through the phenylpropanoid pathway (Figure 7), starting from the amino acid phenylalanine [21], which is, in turn, a product of the shikimate pathway; the latter links carbohydrate metabolism to the biosynthesis of aromatic amino acids and secondary metabolites shikimate pathway [22].

The phenylpropanoid pathway leads to different classes of compounds which can be can be simply classified into flavonoids and nonflavonoids, or be subdivided in many subclasses depending on the structural diversity. This arises from the number of phenol units within the structure, substituent groups, variations in hydroxylation pattern and/or the linkage type between phenol units.

The flavonoid pathway (calchone synthase) leads to the synthesis of six major classes of metabolites, such as flavonols, flavan-3-ols, anthocyanidins, proanthocyanidins and anthocyanins. All these compounds share the basic structure of diphenyl propanes (C6-C3C6), in which phenolic rings (ring A and ring B) are usually linked by a heterocyclic ring (ring C), which usually is a closed pyran, as shown in Figure 8 [23].

Most flavonoids occur in edible plants and foods as $\beta$-glycosides, bound to one or more sugar units with the exception of flavan-3-ols (catechins and proanthocyanidins) and glycosylated isoflavones that are exposed to microbial $\beta$-glucosidases, which catalyze the hydrolysis of the glycosidic bond.

\subsection{Naringenin}

Naringenin is a flavorless, colorless flavanone with three hydroxy groups at the 7,5 and $4^{\prime}$ carbons (Figure 9) [24]. It may be found both in the aglycol form, naringenin (a), or in its glycosidic form, naringin (b), which has the addition of the disaccharide neohesperidose attached via a glycosidic linkage at carbon. 
Entering the flavone synthesis pathway, enzyme chalcone synthase (CHS) catalyzes consecutive condensations of three equivalents of malonyl $\mathrm{CoA}$ followed by aromatization to convert starting p-coumaroyl-CoA to chalcone [25]. Chalcone isomerase (CHI) performs stereospecific isomerization of tetrahydroxychalcone to (2S)-flavanone, which is the branch point precursor of many important downstream flavonoids, including flavones (Figure 10).

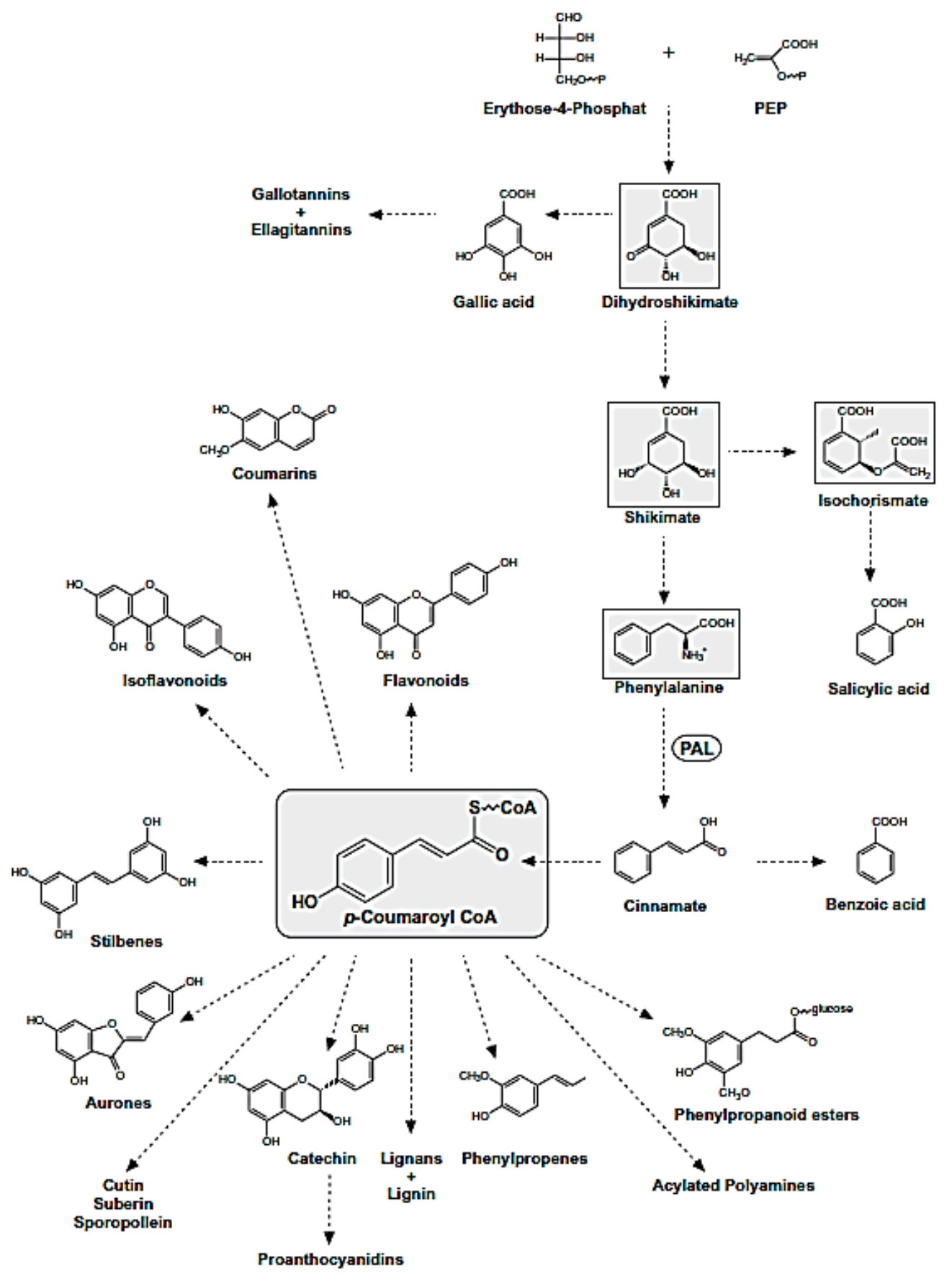

Figure 7. Phenylpropanoid Pathway. The metabolites of the shikimate pathway and p-coumaroyl CoA are shaded in grey.

\subsection{Kaempferol}

Kaempferol (3,5,7-trihydroxy-2-(4-hydroxyphenyl)-4H-chromen-4-one) is a natural flavonol found in common foods derived from plants and fruits. It is biosynthesized from naringenin via a 2-hydroxy intermediate (Figure 12). 
<smiles>OC1Cc2ccccc2OC1c1ccccc1</smiles>

flavan-3-ols<smiles></smiles>

anthocyanidins<smiles>O=c1c(O)c(-c2ccccc2)oc2ccccc12</smiles>

flavonols
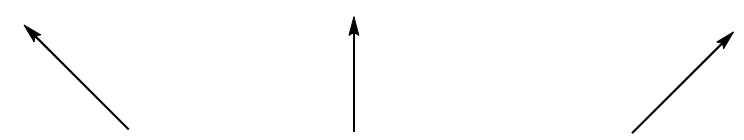

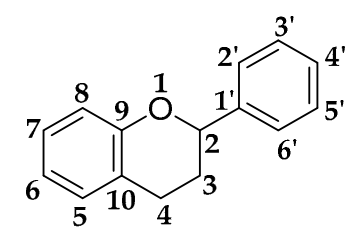<smiles>O=C1CC(c2ccccc2)Oc2ccccc21</smiles>

flavanones<smiles>O=c1c(-c2ccccc2)coc2ccccc12</smiles>

isoflavones

Figure 8. Basic structures of flavonoid subclasses.<smiles>O=C1C[C@H](c2ccc(O)cc2)Oc2cc(O)cc(O)c21</smiles>

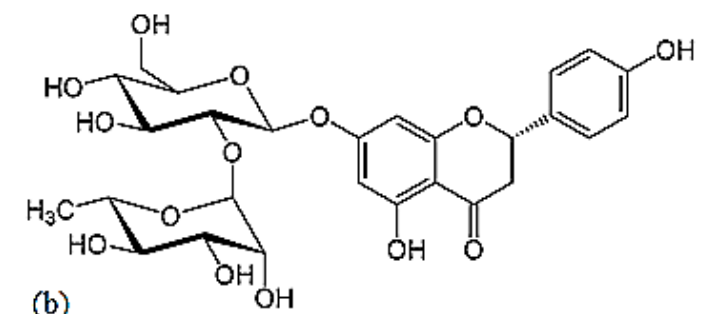

Figure 9. Structures of naringenin (a) and naringin (b).<smiles>O=C(Cl)SC(=O)/C=C/c1ccc(O)cc1</smiles><smiles>O=C(O)CC1CCCCC1</smiles><smiles>O=C(/C=C/c1ccc(O)cc1)c1c(O)cc(O)cc1O</smiles>

CHI<smiles>O=C1CC(c2ccc(O)cc2)Oc2cc(O)cc(O)c21</smiles>

Figure 10. Biosynthetic pathway of naringenin. 


\subsection{Apigenin}

Apigenin (4',5,7-trihydroxyflavone), is a natural product belonging to the flavone class that is the aglycone of several naturally occurring glycosides. It is a yellow crystalline solid that has been used to dye wool. The approximately 650 known flavones arise from flavanones by oxidative processes catalyzed by a flavanone synthase (FNS) enzyme (Figure 11) [26]. Two types of FNS have previously been described; FNS I, a soluble enzyme that uses 2-oxogluturate, $\mathrm{Fe} 2+$ and ascorbate as cofactors and FNS II, a membrane bound, NADPH dependent cytochrome p450 monooxygenase [27].<smiles>CC(C)(C)C1CC(=O)c2c(O)cc(O)cc2OC1c1ccc(O)cc1C1CC(=O)c2c(O)cc(O)cc2OC1(O)c1ccc(O)cc1</smiles>

Figure 11. Biosynthetic pathway of apigenin.<smiles>CC(C)(C)C1CC(=O)c2c(O)cc(O)cc2OC1c1ccc(O)cc1</smiles>

Figure 12. Biosynthesis of kaempferol.

\subsection{Hesperidin}

Hesperidin is a flavanone glycoside found in citrus isolated in 1828 by French chemist Lebreton from the white inner layer of citrus peels (mesocarp, albedo) [28]. The structure consists of a flavanone aglycone, hesperetin, similar to naringenin, which differs from it for the different pattern of substitution on the B ring, which is functionalized with hydroxy group on $3^{\prime}$ carbon and methoxy group on $4^{\prime}$ carbon, whereas the naringenin lacks the methoxy group (Figure 13) [29].<smiles>COc1ccc([C@H]2CC(=O)c3c(O)cc(OC4OCCO[C@@H]5O[C@H](C)C(O)[C@H](O)[C@H]5O4)cc3O2)cc1O</smiles>

Figure 13. Structure of hesperidin. 


\subsection{Ellagic Acid}

Ellagic acid is 2,3,7,8-tetrahydroxy[1]benzo-pyrano-[5,4,3-cde] [1] benzopyran-5,10dione [30]. It is formed by dimerization of gallic acid by oxidative coupling with intramolecular lactonization of both carboxylic acid groups; thus, it is a dilactone of the dimer of gallic acid (Figure 14).<smiles>CC(C)(C)C(=O)O</smiles>

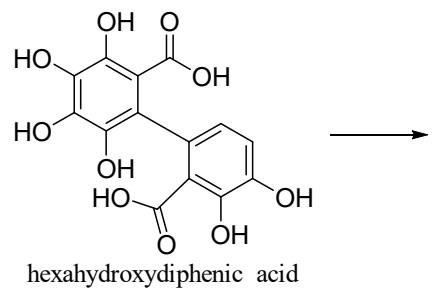<smiles>O=C1Oc2c(O)c(O)cc3c2c(=O)oc2c(O)c(O)cc1c23</smiles>

Figure 14. Gallic and ellagic acids.

\subsection{Oleuropein}

Oleuropein is a glycosylated secoiridoid produced by secondary metabolism of plants and is present in all olive tissues. The term oleuropein is derived from the botanical name of the olive tree, Olea europaea. Oleuropein is an ester of elenolic acid with 3,4dihydroxyphenylethanol (hydroxytyrosol), which is linked to a unit of glucose by a $\beta$ glycosidic bond (Figure 15) [31].<smiles>COC(=O)C1=COC(C)C(CC(=O)O)C1CC(=O)O</smiles>

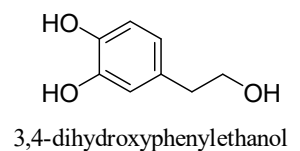

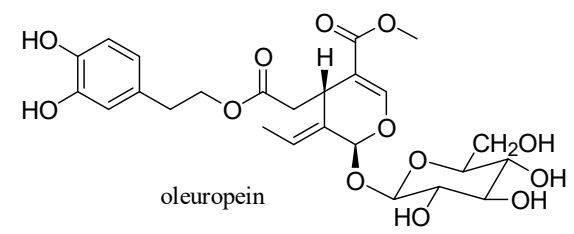

Figure 15. Structure of oleuropein.

Secoiridoid conjugates that contain an esterified phenolic moiety, such as oleuropein, result from a branching in the mevalonic acid pathway in which terpene synthesis (oleoside moiety) and phenylpropanoid metabolism (phenolic moiety) merge [32]. This is illustrated schematically in Figure 16.

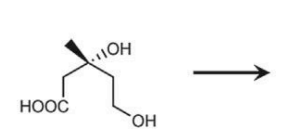

Mevalonic acid<smiles>CC(C)=CCC(C)CO</smiles>
Geraniol

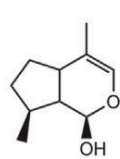

Iridoidal

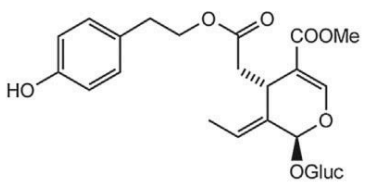

Ligstroside<smiles>C/C=C1\[C@H](CC(=O)OCCc2ccc(O)c(O)c2)OC=C(C(=O)OCCCCC)[C@H]1OC</smiles><smiles>C/C=C1\[C@H](CC(=O)OCCOCCO)OC=C(C(=O)OCCc2ccc(O)c(O)c2)[C@H]1OC</smiles>
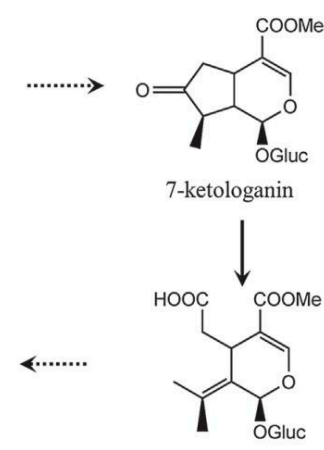

Oleoside 11-methyl ester

Figure 16. A simplified scheme of the oleuropein biosynthesis. 


\section{4. microRNAs}

MicroRNAs (miRs) are a unique class of short endogenous RNAs. They are singlestranded non-coding RNAs able to modulate gene expression by binding to the complementary regions of $3^{\prime} \mathrm{UTR}$ sequence of specific mRNA targets. With this biochemistry, miRs allows mRNA degradation or inhibits translation. The peculiar regulatory capability makes them crucial for normal development in plants and animals [33]. In the area of molecular biology, it is generally accepted that miRNAs have evolved independently in distinct lineages. However, recent studies on miRs in non-bilaterian metazoans, plants and several algae raise the possibility that the last common ancestor of both lineages might have employed a miRs pathway for post-transcriptional regulation [33]. Antioxidant and microRNAs are an emerging field of research, especially in regard to polyphenols epigenetic ability [34]. To date, searching PubMed with the words "polyphenols and microRNAs" shows that 209 papers are currently present (accessed on 25 January 2021 at 7:00 p.m.). Focusing the search to "Naringenin and microRNAs", "Apigenin and microRNAs", "Kaempferol and microRNAs", "Hesperidin and microRNAs", "Ellagic Acid and microRNAs", and "Oleuropein and microRNA" produced six papers for naringenin and microRNAs, 19 on apigenin and microRNAs, 22 on kaempferol and microRNAs, six on hesperidin and microRNAs, 14 on ellagic acid and microRNAs and eight on oleuropein and microRNAs.

\subsection{Naringenin}

The polyphenols naringenin was tested in diverse cell systems displaying epigenetic property by regulating miRs, which in turn regulates the gene expression profile.

Naringenin treatment protects trophoblasts and endothelial cells from the harmful high glucose environment by downregulating the miR-140-3p. In the interim, insulin receptor alpha and insulin-like growth factor 1 receptor expression were upregulated and the glucose uptake increased in naringenin treated trophoblasts and endothelial cells. Therefore, naringenin was proposed by Zhao et al. as a treatment candidate, for gestational diabetes [35]. Another evidence into the diabetes field by naringenin comes from its capability to ameliorated kidney injury through the let-7a. Yan et al. using mesangial cells (MMCs) and diabetic rats as experimental models demonstrate that naringenin led to an upregulation of let-7a under high glucose conditions affecting the expressions of fibronectin and collagen VI in MMCs. In addition, let-7a upregulation in renal tissue diminished the expression of transforming growth factor- $\beta 1$ receptor 1 (TGFBR1), required for the regulation of Let-7a/TGFBR1 signaling pathway in diabetic nephropathy [36]. Naringenin has neuroprotective. In fact, in PC12 cells naringenin decreased the expression of miR-224-3p in a dose-dependent manner and increased the expressions of SOD1 mRNA and protein [37]. Furthermore, in rats, after spinal cord injury, the protective effect of naringenin was exerted through the repression of $\mathrm{miR}-223$. This miR is a fine-tuner granulocyte production playing a fundamental role on neutrophils activation of the inflammatory response [38].

In lung cancer, naringenin biochemical activity inhibits migration and invasion, as well as tumor growth, through the regulation of the microRNA-3619-5p, which belong to a regulating axis with circular RNA FOXM1 and sperm-associated antigen 5 [39]. Lastly, Curti et al. recently demonstrate that naringenin is able to affect the miR-17-3p involved in the control of antioxidant endogenous system [40]. Using a Caco cell, a well characterized in vitro model which mimics the intestinal barrier, it is demonstrated that single enantiomers of naringenin $\mathrm{R}$ and $\mathrm{S}$ have similar activity on this miR, while their equimolar racemic mixture does not [41].

\subsection{Apigenin}

Apigenin in hepatocellular carcinoma cell line was noted to upregulate miR-520b and miR-101 to inhibit tumor growth. The miRs miR-520b and miR-101 are involved in Autophagy Related 7 protein (ATG7) and Nfr2 pathways, respectively, sensitize to doxorubicin treatment $[42,43]$. In neuron derivative tumor, $\mathrm{miR} 16, \mathrm{miR}-138$ and $\mathrm{miR}-423$ 
were identified to be modulated by apigenin. In particular, miR-16 in glioma cells was upregulated negatively influencing the cell B cell CLL/lymphoma 2 (BCL2)/NFkB/Matrix Metallopeptidase 9 (MMP9) axis [44]. Similarly, in neuroblastoma cell, apigenin increased the expression of miR-138, while in glioma, stem cells knockdown miR-423 enhances sensitivity to apigenin involving the mitochondrial cell death pathways $[45,46]$.

Apigenin could inhibit differentiation in TGF- $\beta 1$-stimulated cardiac fibroblast, as well the synthesis of extra cellular matrix (ECM) component. This mechanism might partly be attributable to the reduction of miR-155-5p which control the c-Ski expression and the axis in which is involved, which might result in the inhibition of small mother against decapentaplegic (Smad)2/3 and p-Smad2/3 expressions [47].

Apigenin alleviates myocardial reperfusion injury (RI) in rats by downregulating miR-15b. This miR was found to be increased during myocardial RI, determining a downregulation of JAK2 that promotes myocardial apoptosis and ROS production, aggravating the myocardial injury. Apigenin treatment can downregulate miR-15b expression and increase the expression of Janus kinase 2 (JAK2) and the activity of Signal transducer and activator of transcription 3 (STAT3) pathway, reducing myocardial apoptosis and ROS production and alleviating myocardial RI [48]. Lastly, in mice, apigenin improved glucose intolerance by suppression of matured miR103 expression levels [49]. Apigenin normalized let-7f expression in epididymal fat tissues preventing colonic inflammation, associated with high fat diet-induced obesity [50]. Linked to lipids metabolism a liver-specific microRNA, miR-122, is also an important factor for hepatitis $C$ virus (HCV), replication. Apigenin, in vitro, significantly reduced mature miR122 expression levels in a dose-dependent manner. Therefore, its intake, either via regular diet or supplements, may decrease HCV replication in chronically infected patients [51].

\subsection{Kaempferol}

In human lung cancer cells, kaempferol was able to up-regulate miR-340, along with the inactivation of the phosphatidylinositol-3-kinase (PI3K)/AKT pathways [52]. Likewise, in hepatocellular carcinoma cell line it remarkably reduces the expression of miR-21 leading to the inactivation of the same PI3K/AKT pathway [53]. Kaempferol is known to induce cardioprotective effects. In human aortic endothelial cells (HAECs), kaempferol induced the upregulation of miR-26a-5p, which, targeting the toll-like receptor 4 (TLR4), was able to inactivate the TLR4/nuclear factor kappa B (NF- $\mathrm{BB}$ ) signaling pathway. This biochemical mechanism improves the oxidized low-density lipoprotein-stimulated HAECs [54]. In the same cell system, kaempferol increased miR-203 reversing the results led by lipopolysaccharides (LPS)-induced inflammatory injury [55]. In vascular smooth muscle cell (VSMC), kaempferol induces miR-21 expression inhibiting of cell migration [56]. The myocardial protective property of kaempferol was confirmed in ischemic heart disease (IHD), using primary cardiomyocytes and myoblast cell line H9c2. Under oxygen-glucose deprivation kaempferol exposure promoted the down-regulation of miR-15b, which target Bcl-2 and TLR4 [57]. Furthermore, kaempferol enhanced miR-21 level in H9c2 cells exposed to hypoxia/reoxygenation $(\mathrm{H} / \mathrm{R})$ and inhibition of miR-21 induced by transfection with miR-21 inhibitor significantly blocked the protection of kaempferol against H/R-induced H9c2 cell injury. Furthermore, kaempferol eliminated H/R-induced oxidative stress and inflammatory response by the decreases in ROS generation and malondialdehyde content, as well as the increase in antioxidant enzyme superoxide dismutase and glutathione peroxidase activities [58]. Kaempferol exerts anti-inflammatory activities and has been recognized as an effective agent for alleviating the clinical symptoms of osteoarthritis (OA) by decreasing miR-146a in the chondrogenic cell line ATDC5 activated PI3K/AKT/mTOR signaling pathway. In a rat model of OA, the expression of miR-146a in cartilage tissues was repressed by kaempferol [59].

In osteoblast precursor cell line MC3T3-E1, kaempferol enhanced the expression level of miR-101 promoting osteoblast proliferation, migration and differentiation [60]. 


\subsection{Hesperidin}

Aberrant oxidative stress was implicated in the environmental contaminant Di-(2ethylhexyl) phthalate (DEHP)-induced testicular toxicity in which the miR-126-3p and the miR-181a are overexpressed. Hesperidin administration normalized their levels beside to other biochemical markers [61]. To the best of our knowledge, the present study demonstrated for the first time that the administration of hesperidin decreased the expression of ZEB2 by upregulating the expression of miR 132, which in turn promoted apoptosis and inhibited the proliferation of NSCLC cells [62]. Pre-treatment with hesperidin $(25,50,100 \mathrm{mg} / \mathrm{kg})$ for 7 days prevented these abnormalities induced by LPS injection. In contrast, this effect of hesperidin was abolished by a miRNA-132 antagomir. Taken together, these results suggest that the antidepressant-like mechanisms of hesperidin are at least partially related to decreased pro-inflammatory cytokine levels via the miRNA-132 pathway in the brain [63].

\subsection{Ellagic Acid}

In high glucose-induced T2DM HepG2 cells, ellagic Acid (EA) was able to elevate the miR-223 expression level, downregulating both, mRNA and protein levels of keap1. This led to the upregulation of Nrf2, SOD1 and SOD2 protein levels. Therefore, EA ameliorates oxidative stress and insulin resistance in the cell system used as model [64]. Another beneficial biochemical activity of EA was evident in ventricular remodeling after myocardial infarction. EA improved ventricular remodeling by up-regulating miR-140-3p expression and inhibiting MKK6 expression [65].

\subsection{Oleuropein}

In ovarian cancer was induced in xenograft mice model. Mice exposed to radiation with the simultaneous administration of oleuropein. Oleuropein sensitized ovarian cells to radiation altering the expression of $\mathrm{miR}-299$. This miR was suppressed by a hypoxia inducible factor and relieved in response to oleuropein, which in turn suppressed heparanase 1 expression and consequently led to increased sensitivity to radiation due to synergistic effect of oleuropein with radiation [66]. Similarly, in nasopharyngeal carcinoma, oleuropein strongly enhanced radio-sensitivity through the downregulation of miR-519d [67].

\section{Pharmacokinetic Profile}

Results from a growing number of studies unveiled polyphenols as promising therapeutic agents due to their broad spectrum of biological activities; however, the effectiveness of these compounds in disease prevention and human health improvement is tightly related and limited to their bioavailability [68]. The concept of bioavailability encompasses several variables such as intestinal absorption, metabolism by gut microbiota, intestinal and liver metabolism, biological properties of metabolites, distribution at tissues level and excretion which in turn depend upon the chemical structure of xenobiotics. In addition, the various chemical forms of polyphenols lead to high variability in their rate and extent of intestinal absorption, as well as in the nature of circulating metabolites. Currently there is an increasing interest in biological properties of apigenin owing to it proved relatively low toxicity and effectiveness on cells with impaired biochemistry, such as cancer cells [69]. According to biopharmaceutics classification system (BCS) that correlates in vitro dissolution with in vivo bioavailability, Apigenin is categorized as BCS class II drug due to its low solubility and high permeability. Absorption of this compound occurs in the small intestine by both passive and carrier-mediated saturable mechanism [70]; furthermore, the gastrointestinal tract plays a crucial role in the metabolism and conjugation of apigenin before the entry of the compound into the systemic circulation and the liver [71]. It is worth mentioning that apigenin is naturally present in plants as glycosides. It has been hypothesized that apigenin glucosides can be hydrolyzed into apigenin by cytosolic $\beta$-glucosidase (CBG) and lactase-phlorizin hydrolase (LPH), which are enzymes produced by the liver, intestinal cells or the gut microbiota $[70,72,73]$. LPH has been shown to hydrolyze flavonoid glycosides 
and the resulting aglycone may then enter epithelial cells by passive diffusion [74]. The absorbed apigenin undergoes extensive Phase I and Phase II metabolism [75], accounting for the low bioavailability of the compound.

\subsection{Naringenin}

The gut microbiota also plays a crucial role in the naringenin low availability as it determines extensive pre-systemic metabolism of the compound leading to the formation of degradation products such as phenolic acids [76]. As naringenin, hesperidin has limited bioavailability due to the presence of the rutosin moiety. The removal of either rutinoside or rhamnose from the molecule improves bioavailability and promotes a faster achievement of the maximum plasma concentration [77].

\subsection{Apigenin}

In both rats and humans, apigenin has been documented to produce glucuronide, sulfate conjugates or luteolin as major metabolites [78,79]. In addition, glucuronidation reactions also occur in the intestine and intestinal disposition may be more important than hepatic one in the first-pass metabolism of apigenin [78]. Of note, this natural flavone modulates efflux proteins, especially P-glycoprotein (P-gp) and metabolic enzyme CYP3A4, thus inducing clinically relevant drug-drug interactions by alteration of bioavailability and distribution profiles of targeted drug such as TK inhibitors or paclitaxel [72]. The elimination of Apigenin takes place through urine and feces and it is a slow process, therefore an accumulation of the flavone in tissues seems possible [72].

\subsection{Kaempeferol}

Kaempferol shows up a more favorable bioavailability profile. Absorption of the compound occurs in the small intestine through passive and facilitated diffusion or active transport [80]. Following absorption phase kaempferol undergoes metabolic transformation in the glucuronides and sulfoconjugates forms at both liver [81] and small intestine by enteric conjugation enzymes [80]. Kaempferol and its glycosides are also metabolized in the colon by the bacterial microflora that releases the aglycones and broke aglycone C3 ring to form compounds (i.e., 4-methylphenol, phloroglucinol and 4-hydroxyphenylacetic acid) that are either be absorbed and distributed to tissues by systemic circulation or be excreted in feces and urine [82-85]. Of note, combination of kaempferol with quercetin increase its bioavailability, thus improving its biological efficacy [86].

\subsection{Hesperidin}

Hesperidin bioavailability is also affected by various conditions including the health status [87] and the concomitant administration of this compound with other flavonoids such as quercetin, rutin, daidzein and chrysin [88]. Hesperidin requires deglycosylation into hesperitin by gut microflora to be absorbed. The absorption phase occurs at the level of colonocytes by proton-coupled active transport and transcellular passive diffusion $[89,90]$. Hesperitin is then selectively metabolized into the liver to eriodictyol by both the cytochrome P450 isoforms CYP1A and CYP1B1. Afterward, eriodictyol undergoes methylation and it is transformed to homoeriodictyol (3'-O-methylated) or hesperitin $4^{\prime}$-O-methylated. The other hesperitin metabolites comprise hesperitin glucuronides (7-Oglucuronide and $3^{\prime}$-O-glucuronide, hesperitin sulfates, 7-O- and $3^{\prime}$ - $O$-sulfate, hesperitin sulfoglucuronides and homoeriodictyol glucuronides. It is worth mentioning that the first-pass metabolism of hesperitin occurs in intestinal cells leading to the formation of hesperitin 7-O-glucuronide and 3'-O-glucuronide, which represents the major hesperitin metabolites in vivo [91,92]. Hesperitin is also a selective inhibitor of cytochrome P450 CYP1B1 [93]. This observation provides a possible explanation of the compound antitumor activity being the enzyme involved in facilitating carcinogenesis process. Moreover, hesperitin enhances bioavailability of co-administered drugs such as diltiazem, verapamil and vincristine through inhibition of CYP3A4 or P-gp efflux [94-96]. The metabolites of 
hesperidin/hesperitin are detected in urine but not in feces, thus suggesting a further bacterial degradation to ring fission products and phenolic acids in the colon [97].

\subsection{Ellagic Acid}

The poor systemic bioavailability also affects the mechanism of action across conditions and doses of ellagic acid (EA) as demonstrated by several in vivo studies [98]. In fruits and nuts, EA exists in either its free form, as EA-glycosides, or bound as ellagitannin (ET) $[99,100]$. However, only a small portion of free EA is absorbed in the stomach, since ET are resistant to acidic $\mathrm{pH}$. ET hydrolysis occurs in the small intestine, yielding to the release of EA. This latter is absorbed mainly by passive diffusion, although the involvement of a protein-mediated transport cannot be ruled out as suggested by in vitro experiment on Caco-2 cells line model [101]. In the systemic circulation, EA undergoes a massive first pass effect, being transformed in methyl esters, dimethyl esters or glucuronides, measurable in human plasma from 1 to $5 \mathrm{~h}$ after ET ingestion [102]. In the meantime, unabsorbed ET and EA fractions are mostly converted to a family of metabolites called urolithins by gut microbiota. Urolithins contain a common lipophilic moiety, thus resulting in a net improvement of bioavailability compared to EA [103]. However, the difference in gut microbiota composition leads to a wide variability in microbial metabolism of EA among individuals. Indeed, humans may produce no urolithins, highly active urolithins or less active urolithin, hence EA consumption may not exert equal health benefits in all subjects [104-106]. The low EA oral bioavailability was also confirmed in human pharmacokinetic studies demonstrating the rapid metabolism of the compound and the existence in the absorption phase of saturable mechanism [107].

\subsection{Oleuropein}

Poor data and often conflicting results exist on the oleuropein pharmacokinetic from EVOO or olive leaves in humans [108-111]. This discrepancy may be due to several factors. Indeed, the route of administration, genotype, age, sex, interaction with food and the different extraction processes deeply affect oleuropein bioavailability [112]. It has been reported that oral oleuropein ingestion is resistant to the stomach acidic $\mathrm{pH}$ and it is quickly absorbed in the small intestine, reaching a maximum plasma concentration earlier than conjugated metabolites of hydroxytyrosol in humans. Of note these latter represented the major fraction of the oleuropein phenolic metabolites in plasma and urine after intake [113], suggesting potential complete metabolization of oleuropein to hydroxytyrosol and other catabolic products. Attention has also been payed to the gut microbiota. In vitro and in vivo approaches demonstrated that oleuropein was rapidly deglycosylated to oleuropein $\mathrm{A}$ by human fecal microbiota and then metabolized into elenolic acid and hydroxytyrosol by microbial esterase activity [114]. Further studies have shown that the conversion of oleuropein into hydroxytyrosol was performed by acid by Lactobacillus plantarum [115] and based on this observation oral granules for the co-delivery of Lactobacillus plantarum and a standardized olive leaf extract were developed in order to promote oleuropein metabolism and ensure high levels of hydroxytyrosol [116].

\section{Health Effects}

\subsection{Naringenin}

Being present in foods known to be beneficial for health, such as citrus fruits and tomatoes, naringenin boasts numerous studies, even if, as happens for all molecules of plant origin, mainly in vivo and in vitro. In this sense, various studies show a favorable action in oncology, as it acts by limiting the progression of the cell cycle and angiogenesis; favoring apoptosis and acting directly on some carcinogens [117-119]. It also shows interesting qualities in the management of type 2 diabetes, obesity and metabolic syndrome; improving insulin sensitivity probably by regulating the action of AMPK, regulating the action of amylases and modulating inflammation via inhibition of NF- $\mathrm{kB}$; beneficial actions are reported on the prevention of liver diseases in particular with an interesting 
mechanism, according to which naringenin should be incorporated in cell membranes thus providing a greater protective action $[120,121]$. Preventive action on neurodegenerative diseases can also be explained with the mechanisms proposed above [121]. Possessing immunomodulatory and antiviral activity, naringenin has also been proposed to support therapies against COVID-19 [122]. As for almost all polyphenols, the main problem is bioavailability, although many studies have used orange juice and not extracts or the molecule as it is; for this reason, different strategies are evaluated to make the molecule more bioavailable, as the doses that should be drawn from in vitro or in vivo studies should be between 25 and $50 \mathrm{mg}$ per $\mathrm{kg}$ of body weight [123,124], even if some studies seem to confirm an absorption or at least a retention by the microbiota, with consequent beneficial action on it, with doses ranging from 200 to $500 \mathrm{mg}$ [125-127]. In a case report by Murugesan et al., an improvement in insulin sensitivity is reported with an orange juice dosage of $150 \mathrm{mg}$ naringenin for eight weeks [128]. In one of the few human studies 48 postmenopausal women took $210 \mathrm{mg}$ of naringenin from grapefruit juice for 6 months, showing a clear benefit on arterial stiffness [129].

\subsection{Apigenin}

Like many substances of plant origin, apigenin has also been used for a long time through sources that are part of traditional medicines or common uses, remembering, in this regard, honey and chamomile $[130,131]$. There are many studies in which apigenin shows a very promising potential as an antioxidant [132] and as an adjuvant for numerous pathological states, such as diabetes, cancer, depression, amnesia and Alzheimer's [131]; on the other hand, the studies on humans are few and the compound is extracted mainly from chamomile. Zick et al. tested a standardized chamomile extract that provided $15 \mathrm{mg}$ of apigenin on 34 patients in double blind versus placebo, evaluating the quality of sleep and therefore the impact on insomnia, showing moderate positive effects: different quantities should probably be tested, as there are no adverse effects [133]. In two other papers $[134,135]$, the effect of apigenin, still supplied as chamomile extract, on anxiety disorders was evaluated: the first followed a protocol with a variable dose from 8 to $13 \mathrm{mg}$ of apigenin; in the second, a constant dose of $18 \mathrm{mg}$ of active ingredients, in both cases, showed positive effects, justifying their use in support of any drug therapy. A very interesting hypothesis comes from the work of Vollmer et al., from which it can be deduced that part of the apigenin is excreted intact with the feces; therefore, it is able to reach the microbiota present in the large intestine and thus positively influence the peculiar function [136].

\subsection{Kaempeferol}

Kaempferol is a polyphenol widespread in food, present in crucifers, but also in other foods used quite commonly in various food cultures. For this reason, there are also evaluations of epidemiological studies which positively correlate its intake with the prevention and treatment of various diseases [137]. A review Kashyap et al. [138] shows conflicting results from epidemiological studies: multiple positive results are highlighted, especially in the chemopreventive action, but not all studies report the same effects [139]. Human studies are not numerous, despite the promising results in vitro and in vivo [140-143]; epidemiological studies show a protective effect from cardiovascular diseases and a decrease in IL6 (with consequent modulation of inflammation) from a dosage of kaempferol included in a range of 2-12 mg per day, combined; however, with other polyphenols [139]; moreover, from an interesting study a protective effect on osteoporysis would result, according to various mechanisms that would lead to a decrease in adipogenesis, an increase in chondrogenesis and osteoblastogenesis [144].

\subsection{Hesperidin}

Hesperidin is the polyphenol most present in oranges and other citrus fruits, whose beneficial effect is well known, but often related to vitamin $C$ and not to polyphenols. The beneficial effects demonstrated in vivo and in vitro are multiple, as for all polyphenols, 
thanks to their chemical structure, the antioxidant action is well present. In addition to this, a neuroprotective action was highlighted, beneficial on the cardiovascular system, bone health, on glycemic regulation and not least on the microbiota [145-147]; the dosages of hesperidin used in human studies vary from a minimum of $200 \mathrm{mg}$ to a maximum of $500 \mathrm{mg}$, remaining, although largely in non-toxic or harmful dosages; some show improved cardiovascular health (64 subjects for 6 weeks $500 \mathrm{mg} /$ day); however, positive effects are also shown in the management of hemorrhoids (70 subjects for 6 months of use), in neuroprotection (more than one study with dosages ranging from 200 to $500 \mathrm{mg} /$ day), in the prevention and treatment of osteoporosis [148-152] and even in sports: $500 \mathrm{mg}$ of hesperidin seems to improve aerobic performance in cyclists, probably thanks to the antioxidant action.

\subsection{Ellagic Acid}

This compound is very often linked to pomegranate; in fact, many papers refer to the use of the juice of the fruit, which, however, contains various polyphenols. In fact, in some cases the juice has proved more effective than the extract itself $[153,154]$. Common with all polyphenols, ellagic acid also has an antioxidant activity, directly and as a regulator of NF-KB $[155,156]$. In addition, in vitro and in vivo, it has also shown a regulatory action on inflammatory prostaglandins and on the onset of atherogenesis; many studies, however, are performed in vitro or in vivo. As for humans, a point to be clarified is the bioavailability and conversion of ellagic acid into urolithin, with relative efficacy of the latter $[157,158]$. It is interesting to note how the suboptimal absorption at the gastrointestinal level makes it available for the microbiota; from some papers, it seems that this favors some bacterial strains favorable for health, such as the Firmicutes: Bacteroidetes ratio [159]. The last study involved 20 subjects by administering $1000 \mathrm{mg}$ of ellagic acid for four weeks. Another area where ellagic acid seems to have a positive effect is that relating to the central nervous system [160]; Ying et al. [161], administered to a group of 150 obese subjects, $50 \mathrm{mg}$ of ellagic acid for 12 weeks, a positive effect was recorded not only on the lipid profile, but also on the BNDF, with improvement of the cognitive capacity of the subjects. Amma et al. [162], evaluated the action of ellagic acid in promoting recovery after an intense weightlifting workout; the study, carried out on nine subjects, showed a modulating effect on all the parameters relating to the antioxidant state, although it should be emphasized, however, that pomegranate juice was provided, and not ellagic acid alone. In the review of Huang et al., no positive effects of glycemic control are evident.

\subsection{Oleuropein}

Oleuropein and its derivatives should represent the center of the Mediterranean diet, as a characteristic of the olive tree and consequently of the olive oil; the benefits, proven in vivo and in vitro are multiple and attributable to various pathways, to mention the antiatherogenic, cardioprotective, anticancer, neuroprotective, antidiabetic, anti-obesity, regulating lipids, antimicrobial and antiviral effects [163], but also others less frequently combined with polyphenols, such as the positive action on osteoarthritis [164] or inflammatory bowel diseases [165] and immunomodulation in general [166]; Somerville et al. [167], tested a supplement containing $100 \mathrm{mg}$ of oleuropein on 32 high school athletes of good level, assessing their tendency to get sick and reported a positive correlation; De Bock et al. [168] demonstrated an improvement in insulin sensitivity by administering a supplement containing about $52 \mathrm{mg}$ of oleuropein and 10mg of hydroxytyrosol to 46 obese subjects, in crossover versus placebo; with the same dosage, Lockyer et al. [169], on 16 subjects, analyzed the action of inflammatory cytokines and cardiovascular health, a modulating action was found in particular on IL8; overall, dosages of oleuropein from 50 to $150 \mathrm{mg}$ per day and/or hydroxytorosol between 10 and $50 \mathrm{mg}$ seem to be safe and effective to ensure an anti-inflammatory and antioxidant effect, which is beneficial in improving various conditions, such as atherosclerosis. Similar to other polyphenols [170,171]. 


\section{Conclusions}

Polyphenols certainly show great potential in assisting nutritionist or physician to cotreat various pathologies with a marked inflammatory component. Indeed, the numerous studies on the Mediterranean diet show how this eating style disfavors the onset of diseases that are the major cause of death worldwide, such as cardiovascular diseases, diabetes and cancer. The contemporary diet, in particular in the West, with the exception of north Europe, is often lacking of fruit and vegetables, the main sources of polyphenols; therefore, the consumption of these food categories should be strongly encouraged. On the other hand, the use of polyphenols as supplements could also have a strong impact on health. Although there are many in vitro and in vivo studies, those performed in humans are few and often not organized in a systematic way. Often the vegetable extract in toto or the vegetable is used, so it is difficult to understand which of the compounds had the predominant effect, also because they often act in synergy. In the current state of knowledge, we strongly recommend the use of fruit and vegetables in the diet and to consider the intake ranging from 50 to $200 \mathrm{mg}$ /day of polyphenols, an amount that can also be doubled in pathological conditions, to ensure a beneficial action, at least from an anti-inflammatory and antioxidant viewpoint. As shown, polyphenols have an epigenetic action in particular on miRNAs, and this could also be a fascinating field of study to evaluate, in a clear and systematic way, even in clinical trials, the action of polyphenols.

Author Contributions: Conceptualization, R.C. and E.C., C.L.T. wrote the dietary sources section; A.F. wrote the chemistry section; E.C. wrote the microRNAs section; M.C.C. wrote the pharmacokinetic profile section; R.C wrote the health effects section; R.C. and E.C wrote the conclusion; M.C.C. coordinated the study. All authors have read and agreed to the published version of the manuscript.

Funding: This research received no external funding.

Conflicts of Interest: The authors declare no conflict of interest.

\section{References}

1. Martínez-Huélamo, M.; Rodríguez-Morató, J.; Boronat, A.; de la Torre, R. Modulation of Nrf2 by Olive Oil and Wine Polyphenols and Neuroprotection. Antioxidants 2017, 26, 73. [CrossRef]

2. Georgoulis, M.; Kontogianni, M.D.; Yiannakouris, N. Mediterranean diet and diabetes: Prevention and treatment. Nutrients 2014, 6, 1406-1423. [CrossRef]

3. Widmer, R.J.; Flammer, A.J.; Lerman, L.O.; Lerman, A. The Mediterranean diet, its components, and cardiovascular disease. Am. J. Med. Sci. 2015, 128, 229-238. [CrossRef]

4. Mentella, M.C.; Scaldaferri, F.; Ricci, C.; Gasbarrini, A.; Miggiano, G.A.D. Cancer and Mediterranean Diet: A Review. Nutrients 2019, 11, 2059. [CrossRef]

5. Zamora-Ros, R.; Knaze, V.; Rothwell, J.A.; Hémon, B.; Moskal, A.; Overvad, K.; Tjønneland, A.; Kyrø, C.; Fagherazzi, G.; Boutron-Ruault, M.C.; et al. Dietary polyphenol intake in Europe: The European Prospective Investigation into Cancer and Nutrition (EPIC) study. Eur J. Nutr. 2016, 55, 1359. [CrossRef]

6. Gollucke, A.P.; Peres, R.C.; Odair, A., Jr.; Ribeiro, D.A. Polyphenols: A nutraceutical approach against diseases. Recent Pat. Food Nutr. Agric. 2013, 5, 214-219.

7. Oliviero, F.; Scanu, A.; Zamudio-Cuevas, Y.; Punzi, L.; Spinella, P. Anti-inflammatory effects of polyphenols in arthritis. J. Sci. Food Agric. 2018, 98, 1653-1659. [CrossRef] [PubMed]

8. Leiherer, A.; Mündlein, A.; Drexel, H. Phytochemicals and Their Impact on Adipose Tissue Inflammation and Diabetes. Vasc. Pharmac. 2013, 58, 3-20. [CrossRef]

9. Domitrovic, R. The Molecular Basis for the Pharmacological Activity of Anthocyans. Curr. Med. Chem. 2011, 18, 4454-4469. [CrossRef] [PubMed]

10. González, R.; Ballester, I.; López-Posadas, R.; Suárez, M.D.; Zarzuelo, A.; Martínez-Augustin, O.; Sánchez de Medina, F. Effects of Flavonoids and Other Polyphenols on Inflammation. Crit. Rev. Food Sci. Nutr. 2011, 51, 331-362. [CrossRef] [PubMed]

11. Carullo, G.; Perri, M.; Manetti, F.; Aiello, F.; Caroleo, M.C.; Cione, E. Quercetin-3-oleoyl derivatives as new gpr40 agonists: Molecular docking studies and functional evaluation. Bioorganic Med. Chem. Lett. 2019, 29, 1761-1764. [CrossRef]

12. Dinu, M.; Pagliai, G.; Casini, A.; Sofi, F. Mediterranean diet and multiple health outcomes: An umbrella review of meta-analyses of observational studies and randomised trials. Eur. J. Clin. Nutr. 2018, 72, 30-43. [CrossRef]

13. Alfa, H.H.; Arroo, R.R.J. Over 3 decades of research on dietary flavonoid antioxidants and cancer prevention: What have we achieved? Phytochem. Rev. 2019, 18, 989-1004. [CrossRef] 
14. Zhou, Y.; Jiang, Z.; Lu, H.; Xu, Z.; Tong, R.; Shi, J.; Jia, G. Recent Advances of Natural Polyphenols Activators for Keap1-Nrf2 Signaling Pathway. Chem. Biodivers. 2019, 16, e1900400. [CrossRef]

15. Salehi, B.; Valere, P.; Fokou, T.; Sharifi-Rad, M.; Zucca, P.; Pezzani, R.; Martins, N.; Sharifi-Rad, J. The Therapeutic Potential of Naringenin: A Review of Clinical Trials. Pharmaceuticals 2019, 12, 11. [CrossRef]

16. Sibel, K.; Sedef, N.E.L. Quercetin, luteolin, apigenin and kaempferol contents of some foods. Food Chem. 1999, 66, $289-292$.

17. McKay, D.L.; Blumberg, J.B. A review of the bioactivity and potential health benefits of chamomile tea (Matricaria recutita L.). Phytother. Res. 2006, 20, 519-530. [CrossRef]

18. Shukla, S.; Gupta, S. Apigenin: A promising molecule for cancer prevention. Pharm. Res. 2010, 27, 962-978. [CrossRef]

19. Benincasa, C.; La Torre, C.; Plastina, P.; Fazio, A.; Perri, E.; Caroleo, M.C.; Gallelli, L.; Cannataro, R.; Cione, E. Hydroxytyrosyl Oleate: Improved Extraction Procedure from Olive Oil and By-Products, and In Vitro Antioxidant and Skin Regenerative Properties. Antioxidants 2019, 8, 233. [CrossRef]

20. Chen, H.; Zuo, Y.; Deng, Y. Separation and determination of flavonoids and other phenolic compounds in cranberry juice by high-performance liquid chromatography. J. Chromatogr. A 2001, 13, 387-395. [CrossRef]

21. Barbaro, B.; Toietta, G.; Maggio, R.; Arciello, M.; Tarocchi, M.; Galli, A.; Balsano, C. Effects of the Olive-Derived Polyphenol Oleuropein on Human Health. Int. J. Mol. Sci. 2014, 15, 18508-18524. [CrossRef]

22. Vogt, T. Phenylpropanoid Biosynthesis. Mol. Plant. 2010, 3, 2-20. [CrossRef]

23. Santos-Sánchez, N.C.; Salas-Coronado, R.; Hernández-Carlos, B.; Villanueva-Cañongo, C. Shikimic Acid Pathway in Biosynthesis of Phenolic Compounds. In Plant Physiological Aspects of Phenolic Compounds, 1st ed.; Soto-Hernández, M., García-Mateos, R., Palma-Tenango, M., Eds.; Huajuapan de León: Oaxaca, Mexico, 2019; p. 1.15.

24. Khoddami, A.; Wilkes, M.A.; Roberts, T.H. Techniques for Analysis of Plant Phenolic Compounds. Molecules 2013, 18, 2328-2375. [CrossRef]

25. Austin, M.B.; Noel, J.P. The chalcone synthase superfamily of type III polyketide synthases. Nat. Prod. Rep. 2003, 20, 79-110. [CrossRef] [PubMed]

26. Martens, S.; Forkmann, G.; Matern, U.; Lukacin, R. Cloning of parsley flavone synthase, I. Phytochemistry 2001, 58, 43-46. [CrossRef]

27. Leonard, E.; Yan, Y.; Lim, K.H.; Koffas, M.A. Investigation of two distinct flavone synthases for plant-specific flavone biosynthesis in Saccharomyces cerevisiae. Appl. Environ. Microbiol. 2005, 71, 8241-8248. [CrossRef]

28. Garg, A.; Garg, S.; Zaneveld, L.J.D.; Singla, A.K. Chemistry and pharmacology of the citrus bioflavonoid hesperidin. Phytother. Res. 2001, 15, 655-669. [CrossRef] [PubMed]

29. Binkowska, I. Hesperidin: Synthesis and characterization of bioflavonoid complex. Sn. Appl. Sci. 2020, 2, 445. [CrossRef]

30. Girish, C.; Pradhan, S.C. Herbal Drugs on the Liver. In Liver Pathophysiology, 1st ed.; Muriel, P., Ed.; Academic Press: Cambridge, MA, USA, 2017; pp. 605-620.

31. El Riachy, M.; Priego-Capote, F.; Rallo, L.L.L.; Luque de Castro, M.D. Hydrophilic antioxidants of virgin olive oil. Part 2: Biosynthesis and biotransformation of phenolic compounds in virgin olive oil as affected by agronomic and processing factors. Eur. J. Lipid Sci. Technol. 2011, 113, 692-707. [CrossRef]

32. Koudounas, K.; Banilas, G.; Michaelidis, C.; Demoliou, C. Stamatis Rigas and Polydefkis Hatzopoulos. A defence-related Olea europaea $\beta$-glucosidase hydrolyses and activates oleuropein into a potent protein cross-linking agent. J. Exp. Bot. 2015, 66, 2093-2106. [CrossRef]

33. Moran, Y.; Agron, M.; Praher, D.; Technau, U. The evolutionary origin of plant and animal microRNAs. Nat. Ecol. Evol. 2017, 1, 27. [CrossRef]

34. Corrêa, T.A.; Rogero, M.M. Polyphenols regulating microRNAs and inflammation biomarkers in obesity. Nutrition 2019, 59, 150-157. [CrossRef]

35. Zhao, C.; Zhao, C.; Zhao, H. Defective insulin receptor signaling in patients with gestational diabetes is related to dysregulated miR-140 which can be improved by naringenin. Int. J. Biochem. Cell Biol. 2020, 128, 105824. [CrossRef]

36. Yan, N.; Wen, L.; Peng, R.; Li, H.; Liu, H.; Peng, H.; Sun, Y.; Wu, T.; Chen, L.; Duan, Q.; et al. Naringenin Ameliorated Kidney Injury through Let-7a/TGFBR1 Signaling in Diabetic Nephropathy. J. Diabetes Res. 2016, 2016, 8738760. [CrossRef]

37. Li, H.; Liu, M.W.; Yang, W.; Wan, L.J.; Yan, H.L.; Li, J.C.; Tang, S.Y.; Wang, Y.Q. Naringenin induces neuroprotection against homocysteine-induced PC12 cells via the upregulation of superoxide dismutase 1 expression by decreasing miR-224-3p expression. J. Biol. Regul. Homeost. Agents 2020, 34, 421-433.

38. Shi, L.B.; Tang, P.F.; Zhang, W.; Zhao, Y.P.; Zhang, L.C.; Zhang, H. Naringenin inhibits spinal cord injury-induced activation of neutrophils through miR-223. Gene 2016, 592, 128-133. [CrossRef]

39. Tan, Z.; Sun, Y.; Liu, M.; Xia, L.; Cao, F.; Qi, Y.; Song, Y. Naringenin Inhibits Cell Migration, Invasion, and Tumor Growth by Regulating circFOXM1/miR-3619-5p/SPAG5 Axis in Lung Cancer. Cancer Biother. Radiopharm. 2020, 00, 1-13. [CrossRef]

40. Cannataro, R.; Caroleo, M.C.; Fazio, A.; La Torre, C.; Plastina, P.; Gallelli, L.; Lauria, G.; Cione, E. Ketogenic Diet and microRNAs Linked to Antioxidant Biochemical Homeostasis. Antioxidants 2019, 8, 269. [CrossRef]

41. Curti, V.; Di Lorenzo, A.; Rossi, D.; Martino, E.; Capelli, E.; Collina, S.; Daglia, M. Enantioselective Modulatory Effects of Naringenin Enantiomers on the Expression Levels of miR-17-3p Involved in Endogenous Antioxidant Defenses. Nutrients 2017, 9, 215. [CrossRef] [PubMed] 
42. Gao, A.M.; Zhang, X.Y.; Hu, J.N.; Ke, Z.P. Apigenin sensitizes hepatocellular carcinoma cells to doxorubic through regulating miR-520b/ATG7 axis. Chem. Biol. Interact. 2018, 280, 45-50. [CrossRef] [PubMed]

43. Gao, A.M.; Zhang, X.Y.; Ke, Z.P. Apigenin sensitizes BEL-7402/ADM cells to doxorubicin through inhibiting miR-101/Nrf2 pathway. Oncotarget 2017, 8, 82085-82091. [CrossRef]

44. Chen, X.J.; Wu, M.Y.; Li, D.H.; You, J. Apigenin inhibits glioma cell growth through promoting microRNA-16 and suppression of BCL-2 and nuclear factor-кB/MMP 9. Mol. Med. Rep. 2016, 14, 2352-2358. [CrossRef] [PubMed]

45. Chakrabarti, M.; Banik, N.L.; Ray, S.K. miR-138 overexpression is more powerful than hTERT knockdown to potentiate apigenin for apoptosis in neuroblastoma in vitro and in vivo. Exp. Cell Res. 2013, 319, 1575-1585. [CrossRef]

46. Wan, Y.; Fei, X.; Wang, Z.; Jiang, D.; Chen, H.; Wang, M.; Zhou, S. miR-423-5p knockdown enhances the sensitivity of glioma stem cells to apigenin through the mitochondrial pathway. Tumour. Biol. 2017, 39, 1010428317695526. [CrossRef]

47. Wang, F.; Fan, K.; Zhao, Y.; Xie, M.L. Apigenin attenuates TGF- $\beta 1$-stimulated cardiac fibroblast differentiation and extracellular matrix production by targeting miR-155-5p/c-Ski/Smad pathway. J. Ethnopharmacol. 2021, 265, 113195. [CrossRef]

48. Wang, P.; Sun, J.; Lv, S.; Xie, T.; Wang, X. Apigenin Alleviates Myocardial Reperfusion Injury in Rats by Downregulating miR-15b. Med. Sci. Monit. 2019, 25, 2764-2776. [CrossRef]

49. Ohno, M.; Shibata, C.; Kishikawa, T.; Yoshikawa, T.; Takata, A.; Kojima, K.; Akanuma, M.; Kang, Y.J.; Yoshida, H.; Otsuka, M.; et al. The flavonoid apigenin improves glucose tolerance through inhibition of microRNA maturation in miRNA103 transgenic mice. Sci. Rep. 2013, 3, 2553. [CrossRef] [PubMed]

50. Gentile, D.; Fornai, M.; Colucci, R.; Pellegrini, C.; Tirotta, E.; Benvenuti, L.; Segnani, C.; Ippolito, C.; Duranti, E.; Virdis, A.; et al . The flavonoid compound apigenin prevents colonic inflammation and motor dysfunctions associated with high fat diet-induced obesity. PLoS ONE 2018, 13, e0195502. [CrossRef] [PubMed]

51. Shibata, C.; Ohno, M.; Otsuka, M.; Kishikawa, T.; Goto, K.; Muroyama, R.; Kato, N.; Yoshikawa, T.; Takata, A.; Koike, K. The flavonoid apigenin inhibits hepatitis C virus replication by decreasing mature microRNA122 levels. Virology 2014, 462-463, 42-48. [CrossRef] [PubMed]

52. Han, X.; Liu, C.F.; Gao, N.; Zhao, J.; Xu, J. Kaempferol suppresses proliferation but increases apoptosis and autophagy by up-regulating microRNA-340 in human lung cancer cells. Biomed. Pharm. 2018, 108, 809-816. [CrossRef]

53. Zhu, G.; Liu, X.; Li, H.; Yan, Y.; Hong, X.; Lin, Z. Kaempferol inhibits proliferation, migration, and invasion of liver cancer HepG2 cells by down-regulation of microRNA-21. Int. J. Immunopathol. Pharm. 2018, 32, 2058738418814341. [CrossRef]

54. Zhong, X.; Zhang, L.; Li, Y.; Li, P.; Li, J.; Cheng, G. Kaempferol alleviates ox-LDL-induced apoptosis by up-regulation of miR-26a-5p via inhibiting TLR4/NF-kB pathway in human endothelial cells. Biomed. Pharm. 2018, 108, 1783-1789. [CrossRef] [PubMed]

55. Cui, S.; Tang, J.; Wang, S.; Li, L. Kaempferol protects lipopolysaccharide-induced inflammatory injury in human aortic endothelial cells (HAECs) by regulation of miR-203. Biomed. Pharm. 2019, 115, 108888. [CrossRef] [PubMed]

56. Kim, K.; Kim, S.; Moh, S.H.; Kang, H. Kaempferol inhibits vascular smooth muscle cell migration by modulating BMP-mediated miR-21 expression. Mol. Cell Biochem. 2015, 407, 143-149. [CrossRef]

57. Li, L.; Shao, Y.; Zheng, H.; Niu, H. Kaempferol Regulates miR-15b/Bcl-2/TLR4 to Alleviate OGD-Induced Injury in H9c2 Cells. Int. Heart J. 2020, 61, 585-594. [CrossRef]

58. Huang, J.; Qi, Z. miR-21 mediates the protection of kaempferol against hypoxia/reoxygenation-induced cardiomyocyte injury via promoting Notch1/PTEN/AKT signaling pathway. PLoS ONE 2020, 15, e0241007. [CrossRef]

59. Jiang, R.; Hao, P.; Yu, G.; Liu, C.; Yu, C.; Huang, Y.; Wang, Y. Kaempferol protects chondrogenic ATDC5 cells against inflammatory injury triggered by lipopolysaccharide through down-regulating miR-146a. Int. Immunopharmacol. 2019, 69, 373-381. [CrossRef]

60. Wang, Y.; Chen, H.; Zhang, H. Kaempferol promotes proliferation, migration and differentiation of MC3T3-E1 cells via upregulation of microRNA-101. Artif. Cells Nanomed. Biotechnol. 2019, 47, 1050-1056. [CrossRef]

61. Helmy, H.S.; Senousy, M.A.; El-Sahar, A.E.; Sayed, R.H.; Saad, M.A.; Elbaz, E.M. Aberrations of miR-126-3p, miR-181a and sirtuin1 network mediate Di-(2-ethylhexyl) phthalate-induced testicular damage in rats: The protective role of hesperidin. Toxicology 2020, 433-434, 152406. [CrossRef]

62. Tan, S.; Dai, L.; Tan, P.; Liu, W.; Mu, Y.; Wang, J.; Huang, X.; Hou, A. Hesperidin administration suppresses the proliferation of lung cancer cells by promoting apoptosis via targeting the miR-132/ZEB2 signalling pathway. Int. J. Mol. Med. 2020, 46, 2069-2077. [CrossRef] [PubMed]

63. Li, M.; Shao, H.; Zhang, X.; Qin, B. Hesperidin Alleviates Lipopolysaccharide-Induced Neuroinflammation in Mice by Promoting the miRNA-132 Pathway. Inflammation 2016, 39, 1681-1689. [CrossRef] [PubMed]

64. Ding, X.; Jian, T.; Wu, Y.; Zuo, Y.; Li, J.; Lv, H.; Ma, L.; Ren, B.; Zhao, L.; Li, W.; et al. Ellagic acid ameliorates oxidative stress and insulin resistance in high glucose-treated HepG2 cells via miR-223/keap1-Nrf2 pathway. Biomed. Pharm. 2019, 110, 85-94. [CrossRef]

65. Wei, D.Z.; Lin, C.; Huang, Y.Q.; Wu, L.P.; Huang, M.Y. Ellagic acid promotes ventricular remodeling after acute myocardial infarction by up-regulating miR-140-3p. Biomed. Pharm. 2017, 95, 983-989. [CrossRef] [PubMed]

66. Xing, Y.; Cui, D.; Wang, S.; Wang, P.; Xing, X.; Li, H. Oleuropein represses the radiation resistance of ovarian cancer by inhibiting hypoxia and microRNA-299-targetted heparanase expression. Food Funct. 2017, 8, 2857-2864. [CrossRef] [PubMed]

67. Xu, T.; Xiao, D. Oleuropein enhances radiation sensitivity of nasopharyngeal carcinoma by downregulating PDRG1 through HIF1 $\alpha$-repressed microRNA-519d. J. Exp. Clin. Cancer Res. 2017, 36, 3. [CrossRef] 
68. Manach, C.; Scalbert, A.; Morand, C.; Remesy, C.; Jimenez, L. Polyphenols: Food sources and bioavailability. Am. J. Clin. Nutr. 2004, 79, 727-747. [CrossRef]

69. Gupta, S.; Afaq, F.; Mukhtar, H. Selective growth inhibitory, cell-cycle deregulatory and apoptotic response of apigenin in normal versus human prostate carcinoma cells. Biochem. Biophys. Res. Commun. 2001, 87, 914-920. [CrossRef]

70. Zhang, D.; Liu, Y.; Huang, Y.; Gao, S.; Qian, S. Biopharmaceutics classification and intestinal absorption study of apigenin. Int. J. Pharm. 2012, 436, 311-317. [CrossRef] [PubMed]

71. Liu, Y.; Hu, M. Absorption and Metabolism of Flavonoids in the Caco-2 Cell Culture Model and a Perused Rat Intestinal Model. Drug Metab. Dispos. 2002, 30, 370-377. [CrossRef]

72. Tang, D.; Chen, K.; Huang, L.; Li, J. Pharmacokinetic properties and drug interactions of apigenin, a natural flavone. Expert Opin. Drug Metab. Toxicol. 2017, 13, 323-330. [CrossRef]

73. Németh, K.; Plumb, G.W.; Berrin, J.G.; Juge, N.; Jacob, R.; Naim, H.Y.; Williamson, G.; Swallow, D.M.; Kroon, P.A. Deglycosylation by small intestinal epithelial cell $\beta$-glucosidases is a critical step in the absorption and metabolism of dietary flavonoid glycosides in humans. Eur. J. Nutr. 2003, 42, 29-42. [CrossRef]

74. Manach, C.; Donovan, J.L. Pharmacokinetics and metabolism of dietary flavonoids in humans. Free Rad. Res. 2004, 38, 771-785. [CrossRef]

75. Cardona, F.; Andrés-Lacueva, C.; Tulipani, S.; Tinahones, F.J.; Queipo-Ortuño, M.I. Benefits of polyphenols on gut microbiota and implications in human health. J. Nutr. Biochem. 2013, 24, 1415-1422. [CrossRef]

76. Kanaze, F.; Bounartzi, M.; Georgarakis, M.; Niopas, I. Pharmacokinetics of the citrus flavanone aglycones hesperetin and naringenin after single oral administration in human subjects. Eur. J. Clin. Nutr. 2007, 61, 472-477. [CrossRef]

77. Londono-Londono, J.; De Lima, V.R.; Jaramillo, C.; Creczynski-Pasa, T. Hesperidin and hesperetin membrane interaction: Understanding the role of 7-O-glycoside moiety in flavonoids. Arch. Biochem. Biophys. 2010, 499, 6-16. [CrossRef]

78. Chen, J.; Lin, H.; Hu, M. Metabolism of flavonoids via enteric recycling: Role of intestinal disposition. J. Pharm. Exp. Ther. 2003, 304, 1228-1235. [CrossRef]

79. Gradolatto, A. Pharmacokinetics and metabolism of apigenin in female and male rats after a single oral administration. Drug Met. Disp. 2004, 33, 49-54. [CrossRef]

80. Crespy, V.; Morand, C.; Besson, C.; Cotelle, N.; Vezin, H.; Demigne, C.; Remesy, C. The splanchnic metabolism of flavonoids highly differed according to the nature of the compound. Am. J. Physiol. 2003, 284, G980-G988. [CrossRef]

81. Yodogawa, S.; Arakawa, T.; Sugihara, N.; Furuno, K. Glucurono- and sulfo-conjugation of kaempferol in rat liver subcellular preparations and cultured hepatocytes. Biol. Pharm. Bull. 2003, 26, 1120-1124. [CrossRef]

82. Barve, A.; Chen, C.; Hebbar, V.; Desiderio, J.; Saw, C.L.; Kong, A.N. Metabolism, oral bioavailability and pharmacokinetics of chemopreventive kaempferol in rats. Biopharm. Drug Dispos. 2009, 30, 356-365. [CrossRef]

83. Bonetti, A.; Marotti, I.; Dinelli, G. Urinary excretion of kaempferol from common beans (Phaseolus vulgaris L.) in humans. Int. J. Food Sci. Nutr. 2007, 58, 261-269. [CrossRef] [PubMed]

84. DuPont, M.S.; Day, A.J.; Bennett, R.N.; Mellon, F.A.; Kroon, P.A. Absorption of kaempferol from endive, a source of kaempferol-3glucuronide, in humans. Eur. J. Clin. Nutr. 2004, 58, 947-954. [CrossRef]

85. Wang, F.M.; Yao, T.W.; Zeng, S. Disposition of quercetin and kaempferol in human following an oral administration of Ginkgo biloba extract tablets. Eur. J. Drug Metab. Pharm. 2003, 28, 173-177. [CrossRef]

86. López-Lázaro, M. A new view of carcinogenesis and an alternative approach to cancer therapy. Mol. Med. 2010, 16, 144-153. [CrossRef]

87. Silberberg, M.; Gil-Izquierdo, A.; Combaret, L.; Remesy, C.; Scalbert, A.; Morand, C. Flavanone metabolism in healthy and tumor-bearing rats. Biomed. Pharm. 2006, 60, 529-535. [CrossRef] [PubMed]

88. Brand, W.; Padilla, B.; Van Bladeren, P.J.; Williamson, G.; Rietjens, I.M. The effect of coadministered flavonoids on the metabolism of hesperetin and the disposition of its metabolites in Caco-2 cell monolayers. Mol. Nutr. Food Res. 2010, 54, 851-860. [CrossRef]

89. Manach, C.; Morand, C.; Gil-Izquierdo, A.; Bouteloup-Demange, C.; Remesy, C. Bioavailability in humans of the flavanone's hesperidin and narirutin after the ingestion of two doses of orange juice. Eur. J. Clin. Nutr. 2003, 57, 235-242. [CrossRef]

90. Nielsen, I.L.F.; Chee, W.S.S.; Poulsen, L.; Offord-Cavin, E.; Rasmussen, S.E.; Frederiksen, H.; Enslen, M.; Barron, D.; Horcajada, M.N.; Williamson, G. Bioavailability is improved by enzymatic modification of the citrus flavonoid hesperidin in humans: A randomized, double-blind, crossover trial. J. Nutr. 2006, 136, 404-408. [CrossRef]

91. Brand, W.; Boersma, M.G.; Bik, H.; Hoek-van den Hil, E.F.; Vervoort, J.; Barron, D.; Meinl, W.; Glatt, H.; Williamson, G.; van Bladeren, P.J.; et al. Phase II metabolism of hesperetin by individual UDP-glucuronosyltransferases and sulfotransferases and rat and human tissue samples. Drug Metab. Dispos. 2010, 38, 617-625. [CrossRef]

92. Matsumoto, H.; Ikoma, Y.; Sugiura, M.; Yano, M.; Hasegawa, Y. Identification and quantification of the conjugated metabolites derived from orally administered hesperidin in rat plasma. J. Agric. Food Chem. 2004, 52, 6653-6659. [CrossRef]

93. Doostdar, H.; Burke, M.D.; Mayer, R.T. Bioflavonoids: Selective substrates and inhibitors for cytochrome P450 CYP1A and CYP1B1. Toxicology 2000, 144, 31-38. [CrossRef]

94. Cho, Y.A.; Choi, D.H.; Choi, J.S. Effect of hesperidin on the oral pharmacokinetics of diltiazem and its main metabolite, desacetyldiltiazem, in rats. J. Pharm. Pharm. 2009, 61, 825-829. [CrossRef] [PubMed]

95. Mitsunaga, Y.; Takanaga, H.; Matsuo, H.; Naito, M.; Tsuruo, T.; Ohtani, H.; Sawada, Y. Effect of bioflavonoids on vincristine transport across blood-brain barrier. Eur. J. Pharm. 2000, 395, 193-201. [CrossRef] 
96. Piao, Y.J.; Choi, J.S. Enhanced bioavailability of verapamil after oral administration with hesperidin in rats. Arch. Pharm Res. 2008, 31, 518-522. [CrossRef] [PubMed]

97. Honohan, T.; Hale, R.L.; Brown, J.P.; Wingard, R.E., Jr. Synthesis and metabolic fate of hesperetin3-14C. J. Agric. Food Chem. 1976, 24, 906-911. [CrossRef]

98. Zuccari, G.; Baldassari, S.; Ailuno, G.; Turrini, F.; Alfei, S.; Caviglioli, G. Formulation Strategies to Improve Oral Bioavailability of Ellagic Acid. Appl. Sci. 2020, 10, 3353. [CrossRef]

99. Amakura, Y.; Okada, M.; Tsuji, A.; Tonogai, Y. High-performance liquid chromatography determination with photodiode array detection of ellagic acid in fresh and processed fruits. J. Chromatogr. B 2000, 896, 87-93.

100. Clifford, M.N.; Scalbert, A. Ellagitannins nature, occurrence and dietary burden. J. Sci. Food Agric. 2000, 80, 1118-1125. [CrossRef]

101. Mao, X.; Wu, L.-F.; Zhao, H.; Liang, W.-Y.; Chen, W.J.; Han, S.-X.; Yang-Pi Cui, Q.Q.; Li, S.; Yang, G.-H.; Shao, Y.-Y.; et al. Transport of Corilagin, Gallic Acid, and Ellagic Acid from Fructus Phyllanthi Tannin Fraction in Caco-2 Cell Monolayers. Evid. Based Complement. Altern Med. 2016, 2016, 9205379. [CrossRef]

102. Mertens-talcot, S.U.; Jilma-Stohlawetz, P.; Rios, J.; Hingorani, L.; Derendorf, H. Absorption metabolism and antioxidant effects of pomegranate. J. Agric. Food Chem. 2006, 54, 8956-8961.

103. Tomás-Barberán, F.A.; García-Villalba, R.; González-Sarrías, A.; Selma, M.V.; Espín, J.C. Ellagic acid metabolism by human gut microbiota: Consistent observation of three urolithin phenotypes in intervention trials, independent of food source, age, and health status. J. Agric. Food Chem. 2014, 62, 6535-6538. [CrossRef]

104. Tomás-Barberán, F.A.; González-Sarrias, A.; Garcı-Villalba, R.; Nunez-Sanchez, M.A.; Selma, M.V.; Garcıa-Conesa, M.T.; Espın, J.C. Urolithins, the rescue of "old" metabolites to understand a "new" concept: Metabotypes as a nexus among phenolic metabolism, microbiota dysbiosis, and host health status. Mol. Nutr. Food Res. 2017, 61, 1500901. [CrossRef] [PubMed]

105. Cortés-Martín, A.; García-Villalba, R.; González-Sarrías, A.; Romo-Vaquero, M.; Loria-Kohen, V.; Ramírez-de-Molina, A.; TomásBarberán, F.A.; Selma, M.V.; Espín, J.C. The gut microbiota urolithin metabotypes revisited: The human metabolism of ellagicacid is mainly determined by aging. Food Funct. 2018, 9, 4100-4106. [CrossRef]

106. Seeram, N.P.; Henning, S.M.; Zhang, Y.; Suchard, M.; Li, Z.; Heber, D. Pomegranate juice ellagitannin metabolites are present in human plasma and some persist in urine for up to $48 \mathrm{~h}$. J. Nutr. 2006, 136, 2481-2485. [CrossRef]

107. González-Sarrías, A.; García-Villalba, R.; Núñez-Sánchez, M.Á.; Tomé-Carneiro, J.; Zafrilla, P.; Mulero, J.; Tomás-Barberán, F.A.; Espín, J.C. Identifying the limits for ellagic acid bioavailability: A crossover pharmacokinetic study in healthy volunteers after consumption of pomegranate extracts. J. Funct. Foods 2015, 19, 225-235. [CrossRef]

108. Visioli, F.; Galli, C.; Bornet, F.; Mattei, A.; Patelli, R.; Galli, G.; Caruso, D. Olive oil phenolics are dose-dependently absorbed in humans. Febs. Lett. 2000, 468, 159-160. [CrossRef]

109. Miró-Casas, E.; Farré Albaladejo, M.; Covas, M.I.; Rodriguez, J.O.; Menoyo Colomer, E.; Lamuela Raventós, R.M.; de la Torre, R. Capillary gas chromatography-mass spectrometry quantitative determination of hydroxytyrosol and tyrosol in human urine after olive oil intake. Anal. Biochem. 2001, 294, 63-72. [CrossRef] [PubMed]

110. Vissers, M.N.; Zock, P.L.; Roodenburg, A.J.C.; Leenen, R.; Katan, M.B. Olive Oil Phenols Are Absorbed in Humans. J. Nutr. 2002, 132, 409-417. [CrossRef]

111. Lemonakis, N.; Mougios, V.; Halabalaki, M.; Skaltsounis, A.-L.; Gikas, E. A novel bioanalytical method based on UHPLCHRMS/MS for the quantification of oleuropein in human serum. Application to a pharmacokinetic study: Quantification of oleuropein in human serum. Biomed. Chromatogr. 2016, 30, 2016-2023. [CrossRef] [PubMed]

112. de Bock, M.; Thorstensen, E.B.; Derraik, J.G.B.; Henderson, H.V.; Hofman, P.L.; Cutfield, W.S. Human absorption and metabolism of oleuropein and hydroxytyrosol ingested as olive (Olea europaea L.) leaf extract. Mol. Nutr. Food Res. 2013, 57, $2079-2085$. [CrossRef]

113. Mosele, J.I.; Martín-Peláez, S.; Macià, A.; Farràs, M.; Valls, R.-M.; Catalán, Ú.; Motilva, M.-J. Faecal microbial metabolism of olive oil phenolic compounds: In vitro and in vivo approaches. Mol. Nutr. Food Res. 2014, 58, 1809-1819. [CrossRef] [PubMed]

114. Santos, M.M.; Piccirillo, C.; Castro, P.M.L.; Kalogerakis, N.; Pintado, M.E. Bioconversion of oleuropein to hydroxytyrosol by lactic acid bacteria. World J. Microbiol. Biotechnol. 2012, 28, 2435-2440. [CrossRef]

115. Aponte, M.; Ungaro, F.; d'Angelo, I.; De Caro, C.; Russo, R.; Blaiotta, G.; Dal Piaz, F.; Calignano, A.; Miro, A. Improving in vivo conversion of oleuropein into hydroxytyrosol by oral granules containing probiotic Lactobacillus plantarum $299 \mathrm{v}$ and an Olea europaea standardized extract. Int. J. Pharm. 2018, 543, 73-82. [CrossRef] [PubMed]

116. Arafah, A.; Rehman, M.U.; Mir, T.M.; Wali, A.F.; Ali, R.; Qamar, W.; Khan, R.; Ahmad, A.; Aga, S.S.; Alqahtani, S.; et al. Multi-Therapeutic Potential of Naringenin (4',5,7-Trihydroxyflavonone): Experimental Evidence and Mechanisms. Plants 2020, 9, 1784. [CrossRef]

117. Lim, W.; Park, S.; Bazer, F.W.; Song, G. Naringenin-Induced Apoptotic Cell Death in Prostate Cancer Cells Is Mediated via the PI3K/AKT and MAPK Signaling Pathways. J. Cell Biochem. 2017, 118, 1118-1131. [CrossRef] [PubMed]

118. Casey, S.C.; Amedei, A.; Aquilano, K.; Azmi, A.S.; Benencia, F.; Bhakta, D.; Bilsland, A.E.; Boosani, C.S.; Chen, S.; Ciriolo, M.R.; et al. Cancer prevention and therapy through the modulation of the tumor microenvironment. Semin. Cancer Biol. 2015, 35, S199-S223. [CrossRef]

119. Alam, M.A.; Subhan, N.; Rahman, M.M.; Uddin, S.J.; Reza, H.M.; Sarker, S.D. Effect of citrus flavonoids, naringin and naringenin, on metabolic syndrome and their mechanisms of action. Adv. Nutr. 2014, 5, 404-417. [CrossRef] [PubMed] 
120. Zaidun, N.H.; Thent, Z.C.; Latiff, A.A. Combating oxidative stress disorders with citrus flavonoid: Naringenin. Life Sci. 2018, 208, 111-122. [CrossRef] [PubMed]

121. Nouri, Z.; Fakhri, S.; El-Senduny, F.F.; Sanadgol, N.; Abd-ElGhani, G.E.; Farzaei, M.H.; Chen, J.T. On the Neuroprotective Effects of Naringenin: Pharmacological Targets, Signaling Pathways, Molecular Mechanisms, and Clinical Perspective. Biomolecules 2019, 9, 690. [CrossRef] [PubMed]

122. Alberca, R.W.; Teixeira, F.M.E.; Beserra, D.R.; de Oliveira, E.A.; Andrade, M.M.S.; Pietrobon, A.J.; Sato, M.N. Perspective: The Potential Effects of Naringenin in COVID-19. Front. Immunol. 2020, 11, 570919. [CrossRef]

123. Joshi, R.; Kulkarni, Y.A.; Wairkar, S. Pharmacokinetic, pharmacodynamic and formulations aspects of Naringenin: An update. Life Sci. 2018, 215, 43-56. [CrossRef] [PubMed]

124. Chen, T.; Su, W.; Yan, Z.; Wu, H.; Zeng, X.; Peng, W.; Gan, L.; Zhang, Y.; Yao, H. Identification of naringin metabolites mediated by human intestinal microbes with stable isotope-labeling method and UFLC-Q-TOF-MS/MS. J. Pharm. Biomed. Anal. 2018, 161, 262-272. [CrossRef] [PubMed]

125. Kay, C.D.; Pereira-Caro, G.; Ludwig, I.A.; Clifford, M.N.; Crozier, A. Anthocyanins and Flavanones Are More Bioavailable than Previously Perceived: A Review of Recent Evidence. Annu. Rev. Food Sci. Technol. 2017, 8, 155-180. [CrossRef] [PubMed]

126. Murugesan, N.; Woodard, K.; Ramaraju, R.; Greenway, F.L.; Coulter, A.A.; Rebello, C.J. Naringenin Increases Insulin Sensitivity and Metabolic Rate: A Case Study. J. Med. Food 2020, 23, 343-348. [CrossRef] [PubMed]

127. Habauzit, V.; Verny, M.A.; Milenkovic, D.; Barber-Chamoux, N.; Mazur, A.; Dubray, C.; Morand, C. Flavanones protect from arterial stiffness in postmenopausal women consuming grapefruit juice for 6 mo: A randomized, controlled, crossover trial. Am. J. Clin. Nutr. 2015, 102, 66-74. [CrossRef] [PubMed]

128. Olas, B. Honey and Its Phenolic Compounds as an Effective Natural Medicine for Cardiovascular Diseases in Humans? Nutrients 2020, 12, 283. [CrossRef] [PubMed]

129. Salehi, B.; Venditti, A.; Sharifi-Rad, M.; Kregiel, D.; Sharifi-Rad, J.; Durazzo, A.; Lucarini, M.; Santini, A.; Souto, E.B.; Novellino, E.; et al. The Therapeutic Potential of Apigenin. Int. J. Mol. Sci. 2019, 20, 1305. [CrossRef] [PubMed]

130. Li, F.; Lang, F.; Zhang, H.; Xu, L.; Wang, Y.; Zhai, C.; Hao, E. Apigenin Alleviates Endotoxin-Induced Myocardial Toxicity by Modulating Inflammation, Oxidative Stress, and Autophagy. Oxid. Med. Cell Longev. 2017, 2017, 2302896. [CrossRef] [PubMed]

131. Zick, S.M.; Wright, B.D.; Sen, A.; Arnedt, J.T. Preliminary examination of the efficacy and safety of a standardized chamomile extract for chronic primary insomnia: A randomized placebo-controlled pilot study. BMC Complement. Altern. Med. 2011, 11, 78. [CrossRef]

132. Amsterdam, J.D.; Shults, J.; Soeller, I.; Mao, J.J.; Rockwell, K.; Newberg, A.B. Chamomile (Matricaria recutita) may provide antidepressant activity in anxious, depressed humans: An exploratory study. Altern. Health Med. 2012, 18, 44-49.

133. Mao, J.J.; Xie, S.X.; Keefe, J.R.; Soeller, I.; Li, Q.S.; Amsterdam, J.D. Long-term chamomile (Matricaria chamomilla L.) treatment for generalized anxiety disorder: A randomized clinical trial. Phytomedicine 2016, 23, 1735-1742. [CrossRef]

134. Vollmer, M.; Esders, S.; Farquharson, F.M.; Neugart, S.; Duncan, S.H.; Schreiner, M.; Louis, P.; Maul, R.; Rohn, S. Mutual Interaction of Phenolic Compounds and Microbiota: Metabolism of Complex Phenolic Apigenin-C- and Kaempferol-O-Derivatives by Human Fecal Samples. J. Agric. Food Chem. 2018, 66, 485-497. [CrossRef] [PubMed]

135. Ren, J.; Lu, Y.; Qian, Y.; Chen, B.; Wu, T.; Ji, G. Recent progress regarding kaempferol for the treatment of various diseases. Exp. Med. 2019, 18, 2759-2776. [CrossRef] [PubMed]

136. Devi, K.P.; Malar, D.S.; Nabavi, S.F.; Sureda, A.; Xiao, J.; Nabavi, S.M.; Daglia, M. Kaempferol and inflammation: From chemistry to medicine. Pharm. Res. 2015, 99, 1-10. [CrossRef] [PubMed]

137. Imran, M.; Rauf, A.; Shah, Z.A.; Saeed, F.; Imran, A.; Arshad, M.U.; Ahmad, B.; Bawazeer, S.; Atif, M.; Peters, D.G.; et al. Chemo-preventive and therapeutic effect of the dietary flavonoid kaempferol: A comprehensive review. Phytother. Res. 2019, 33, 263-275. [CrossRef] [PubMed]

138. Kashyap, D.; Sharma, A.; Tuli, H.S.; Sak, K.; Punia, S.; Mukherjee, T.K. Kaempferol-A dietary anticancer molecule with multiple mechanisms of action: Recent trends and advancements. J. Funct. Foods 2017, 30, 203-219. [CrossRef]

139. Navarro, S.L.; Schwarz, Y.; Song, X.; Wang, C.-Y.; Chen, C.; Trudo, S.P.; Kristal, A.R.; Kratz, M.; Eaton, D.L.; Lampe, J.W. Cruciferous Vegetables Have Variable E_ects on Biomarkers of Systemic Inflammation in a Randomized Controlled Trial in Healthy Young Adults. J. Nutr. 2014, 144, 1850-1857. [CrossRef] [PubMed]

140. Alam, W.; Khan, H.; Shah, M.A.; Cauli, O.; Saso, L. Kaempferol as a Dietary Anti-Inflammatory Agent: Current Therapeutic Standing. Molecules 2020, 25, 4073. [CrossRef] [PubMed]

141. Wong, S.K.; Chin, K.Y.; Ima-Nirwana, S. The Osteoprotective Effects of Kaempferol: The Evidence From In Vivo and In Vitro Studies. Drug Des. Devel. 2019, 13, 3497-3514. [CrossRef]

142. Kim, J.; Wie, M.B.; Ahn, M.; Tanaka, A.; Matsuda, H.; Shin, T. Benefits of hesperidin in central nervous system disorders: A review. Anat. Cell Biol. 2019, 52, 369-377. [CrossRef]

143. Jawien, A.; Bouskela, E.; Allaert, F.A.; Nicolaïdes, A.N. The place of Ruscus extract, hesperidin methyl chalcone, and vitamin C in the management of chronic venous disease. Int. Angiol. 2017, 36, 31-41.

144. Stevens, Y.; Rymenant, E.V.; Grootaert, C.; Camp, J.V.; Possemiers, S.; Masclee, A.; Jonkers, D. The Intestinal Fate of Citrus Flavanones and Their Effects on Gastrointestinal Health. Nutrients 2019, 11, 1464. [CrossRef]

145. Homayouni, F.; Haidari, F.; Hedayati, M.; Zakerkish, M.; Ahmadi, K. Blood pressure lowering and anti-inflammatory effects of hesperidin in type 2 diabetes; a randomized double-blind controlled clinical trial. Phytother. Res. 2018, 32, 1073-1079. [CrossRef] 
146. Salden, B.N.; Troost, F.J.; de Groot, E.; Stevens, Y.R.; Garcés-Rimón, M.; Possemiers, S.; Winkens, B.; Masclee, A.A. Randomized clinical trial on the efficacy of hesperidin $2 S$ on validated cardiovascular biomarkers in healthy overweight individuals. Am. J. Clin. Nutr. 2016, 104, 1523-1533. [CrossRef]

147. Hajialyani, M.; Hosein Farzaei, M.; Echeverría, J.; Nabavi, S.M.; Uriarte, E.; Sobarzo-Sánchez, E. Hesperidin as a Neuroprotective Agent: A Review of Animal and Clinical Evidence. Molecules 2019, 24, 648. [CrossRef]

148. Corsale, I.; Carrieri, P.; Martellucci, J.; Piccolomini, A.; Verre, L.; Rigutini, M.; Panicucci, S. Flavonoid mixture (diosmin, troxerutin, rutin, hesperidin, quercetin) in the treatment of I-III degree hemorroidal disease: A double-blind multicenter prospective comparative study. Int. J. Colorectal. Dis. 2018, 33, 1595-1600. [CrossRef]

149. Martin, B.R.; McCabe, G.P.; McCabe, L.; Jackson, G.S.; Horcajada, M.N.; Offord-Cavin, E.; Peacock, M.; Weaver, C.M. Effect of Hesperidin with and Without a Calcium (Calcilock) Supplement on Bone Health in Postmenopausal Women. J. Clin. Endocrinol. Metab. 2016, 101, 923-927. [CrossRef]

150. Kerimi, A.; Nyambe-Silavwe, H.; Gauer, J.S.; Tomás-Barberán, F.A.; Williamson, G. Pomegranate juice, but not an extract, confers a lower glycemic response on a high-glycemic index food: Randomized, crossover, controlled trials in healthy subjects. Am. J. Clin. Nutr. 2017, 106, 1384-1393. [CrossRef]

151. Long, J.; Guo, Y.; Yang, J.; Henning, S.M.; Lee, R.P.; Rasmussen, A.; Zhang, L.; Lu, Q.Y.; Heber, D.; Li, Z. Bioavailability and bioactivity of free ellagic acid compared to pomegranate juice. Food Funct. 2019, 10, 6582-6588. [CrossRef]

152. Danesi, F.; Ferguson, L.R. Could Pomegranate Juice Help in the Control of Inflammatory Diseases? Nutrients 2017, 9, 958. [CrossRef]

153. Ríos, J.L.; Giner, R.M.; Marín, M.; Recio, M.C. A Pharmacological Update of Ellagic Acid. Planta Med. 2018, 84, 1068-1093. [CrossRef] [PubMed]

154. Alfei, S.; Marengo, B.; Zuccari, G. Oxidative Stress, Antioxidant Capabilities, and Bioavailability: Ellagic Acid or Urolithins? Antioxidants 2020, 9, 707. [CrossRef] [PubMed]

155. Kang, I.; Buckner, T.; Shay, N.F.; Gu, L.; Chung, S. Improvements in Metabolic Health with Consumption of Ellagic Acid and Subsequent Conversion into Urolithins: Evidence and Mechanisms. Adv. Nutr. 2016, 7, 961-972. [CrossRef]

156. Li, Z.; Henning, S.M.; Lee, R.P.; Lu, Q.Y.; Summanen, P.H.; Thames, G.; Corbett, K.; Downes, J.; Tseng, C.H.; Finegold, S.M.; et al. Pomegranate extract induces ellagitannin metabolite formation and changes stool microbiota in healthy volunteers. Food Funct. 2015, 6, 2487-2495. [CrossRef] [PubMed]

157. Ahmed, T.; Setzer, W.N.; Nabavi, S.F.; Orhan, I.E.; Braidy, N.; Sobarzo-Sanchez, E.; Nabavi, S.M. Insights Into Effects of Ellagic Acid on the Nervous System: A Mini Review. Curr. Pharm. Des. 2016, 22, 1350-1360. [CrossRef] [PubMed]

158. Liu, Y.; Yu, S.; Wang, F.; Yu, H.; Li, X.; Dong, W.; Lin, R.; Liu, Q. Chronic administration of ellagic acid improved the cognition in middle-aged overweight men. Appl. Physiol. Nutr. Metab. 2018, 43, 266-273. [CrossRef]

159. Ammar, A.; Turki, M.; Hammouda, O.; Chtourou, H.; Trabelsi, K.; Bouaziz, M.; Abdelkarim, O.; Hoekelmann, A.; Ayadi, F.; Souissi, N.; et al. Effects of Pomegranate Juice Supplementation on Oxidative Stress Biomarkers Following Weightlifting Exercise. Nutrients 2017, 9, 819. [CrossRef]

160. Karković Marković, A.; Torić, J.; Barbarić, M.; Jakobušić Brala, C. Hydroxytyrosol, Tyrosol and Derivatives and Their Potential Effects on Human Health. Molecules 2019, 24, 2001. [CrossRef]

161. D'Adamo, S.; Cetrullo, S.; Panichi, V.; Mariani, E.; Flamigni, F.; Borzì, R.M. Nutraceutical Activity in Osteoarthritis Biology: A Focus on the Nutrigenomic Role. Cells 2020, 9, 1232. [CrossRef]

162. Larussa, T.; Imeneo, M.; Luzza, F. Olive Tree Biophenols in Inflammatory Bowel Disease: When Bitter is Better. Int. J. Mol. Sci. 2019, 20, 1390. [CrossRef]

163. Santangelo, C.; Vari, R.; Scazzocchio, B.; De Sanctis, P.; Giovannini, C.; D’Archivio, M.; Masella, R. Anti-inflammatory Activity of Extra Virgin Olive Oil Polyphenols: Which Role in the Prevention and Treatment of Immune-Mediated Inflammatory Diseases? Endocr. Metab. Immune Disord. Drug Targets 2018, 18, 36-50. [CrossRef]

164. Somerville, V.; Moore, R.; Braakhuis, A. The Effect of Olive Leaf Extract on Upper Respiratory Illness in High School Athletes: A Randomised Control Trial. Nutrients 2019, 11, 358. [CrossRef] [PubMed]

165. de Bock, M.; Derraik, J.G.; Brennan, C.M.; Biggs, J.B.; Morgan, P.E.; Hodgkinson, S.C.; Hofman, P.L.; Cutfield, W.S. Olive (Olea europaea L.) leaf polyphenols improve insulin sensitivity in middle-aged overweight men: A randomized, placebo-controlled, crossover trial. PLoS ONE 2013, 8, e57622. [CrossRef]

166. Lockyer, S.; Corona, G.; Yaqoob, P.; Spencer, J.P.; Rowland, I. Secoiridoids delivered as olive leaf extract induce acute improvements in human vascular function and reduction of an inflammatory cytokine: A randomised, double-blind, placebo-controlled, crossover trial. Br. J. Nutr. 2015, 114, 75-83. [CrossRef] [PubMed]

167. Lopez-Huertas, E.; Fonolla, J. Hydroxytyrosol supplementation increases vitamin C levels in vivo. A human volunteer trial. Redox. Biol. 2017, 11, 384-389. [CrossRef]

168. Quirós-Fernández, R.; López-Plaza, B.; Bermejo, L.M.; Palma-Milla, S.; Gómez-Candela, C. Supplementation with Hydroxytyrosol and Punicalagin Improves Early Atherosclerosis Markers Involved in the Asymptomatic Phase of Atherosclerosis in the Adult Population: A Randomized, Placebo-Controlled, Crossover Trial. Nutrients 2019, 11, 640. [CrossRef]

169. Bellavite, P.; Donzelli, A. Hesperidin and SARS-CoV-2: New Light on the Healthy Function of Citrus Fruits. Antioxidants 2020, 9, 742. [CrossRef] 
170. Dabeek, W.M.; Ventura Marra, M. Dietary Quercetin and Kaempferol: Bioavailability and Potential Cardiovascular-Related Bioactivity in Humans. Nutrients 2019, 11, 2288. [CrossRef] [PubMed]

171. Cione, E.; La Torre, C.; Cannataro, R.; Caroleo, M.C.; Plastina, P.; Gallelli, L. Quercetin, Epigallocatechin Gallate, Curcumin, and Resveratrol: From Dietary Sources to Human MicroRNA Modulation. Molecules 2019, 25, 63. [CrossRef] 